\title{
Plastics in Porifera: the occurrence of potential microplastics in marine sponges and seawater from Bocas del Toro, Panamá
}

\author{
Bailey R Fallon $^{\text {Corresp., } 1}$, Christopher J Freeman ${ }^{1}$ \\ ${ }^{1}$ Department of Biology, College of Charleston, Charleston, SC, United States \\ Corresponding Author: Bailey R Fallon \\ Email address: fallonbr@g.cofc.edu
}

Microplastics (MP) are now considered ubiquitous across global aquatic environments. The ingestion of MP by fish and other marine vertebrates is well studied, but the ingestion of MP by marine invertebrates is not. Sponges (Phylum Porifera) are particularly understudied when it comes to MP ingestion, even though they are widely distributed across benthic habitats, can process large volumes of seawater, and can retain small particles within their water filtration systems. This study examines the presence of potential MP (PMP) in wild marine sponges and seawater collected in Bocas del Toro, Panamá. Subsurface seawater and tissue from six common Caribbean sponge species was collected in Saigon Bay, a heavily impacted, shallow-water coral reef. Seawater samples were filtered onto glass fiber filters to retain any PMP present and sponge tissue was digested with bleach, heated and filtered. Filters were examined using fluorescence microscopy to quantify PMP. An average of $107 \pm 25 \mathrm{PMP} \mathrm{L}^{-1}$ was detected in seawater from Saigon Bay with particles ranging in size between $10 \mu \mathrm{m}$ and $\sim 3000 \mu \mathrm{m}$. The number of PMP found in sponge tissue ranged between $6 \pm 4$ and $169 \pm 71 \mathrm{PMP} \mathrm{g}^{-1}$ of dry tissue. Most particles found in sponge samples were very small (10-20 $\mu \mathrm{m})$, but fibers greater than $5000 \mu \mathrm{m}$ were detected. Our results indicate that PMP exists within the tissues of the sponges we studied, but future studies should confirm the presence of MP in sponges using chemical analysis. Most importantly, the discrepancy between low levels of PMP in our sponge samples and high levels in the surrounding seawater highlights the potential for sponges to resist and/or egest MP.

Finally, we provide a critical evaluation of our methods to improve their use in future MP work with benthic marine organisms. 
1 Plastics in Porifera: the occurrence of potential

2 microplastics in marine sponges and seawater from Bocas

3 del Toro, Panamá

4

5

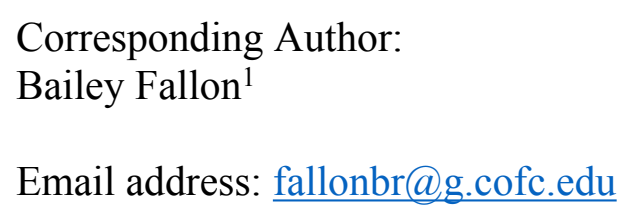

Bailey Fallon ${ }^{1}$

\section{5}

16

17

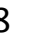

9


30

31

32

\section{Abstract}

Microplastics (MP) are now considered ubiquitous across global aquatic environments. The ingestion of MP by fish and other marine vertebrates is well studied, but the ingestion of MP by marine invertebrates is not. Sponges (Phylum Porifera) are particularly understudied when it comes to MP ingestion, even though they are widely distributed across benthic habitats, can process large volumes of seawater, and can retain small particles within their water filtration systems. This study examines the presence of potential MP (PMP) in wild marine sponges and seawater collected in Bocas del Toro, Panamá. Subsurface seawater and tissue from six common Caribbean sponge species was collected in Saigon Bay, a heavily impacted, shallow-water coral reef. Seawater samples were filtered onto glass fiber filters to retain any PMP present and sponge tissue was digested with bleach, heated and filtered. Filters were examined using fluorescence microscopy to quantify PMP. An average of $107 \pm 25 \mathrm{PMP} \mathrm{L}^{-1}$ was detected in seawater from Saigon Bay with particles ranging in size between $10 \mu \mathrm{m}$ and $\sim 3000 \mu \mathrm{m}$. The number of PMP found in sponge tissue ranged between $6 \pm 4$ and $169 \pm 71 \mathrm{PMP} \mathrm{g}^{-1}$ of dry tissue. Most particles found in sponge samples were very small $(10-20 \mu \mathrm{m})$, but fibers greater than $5000 \mu \mathrm{m}$ were detected. Our results indicate that PMP exists within the tissues of the sponges we studied, but future studies should confirm the presence of MP in sponges using chemical analysis. Most importantly, the discrepancy between low levels of PMP in our sponge samples and high levels in the surrounding seawater highlights the potential for sponges to resist and/or egest MP. Finally, we provide a critical evaluation of our methods to improve their use in future MP work with benthic marine organisms. 


\section{Introduction}

54 As humans continue to expand across the globe, our collective impact on the environment is amplified (Crutzen, 2002; Zalasiewicz et al., 2010; Lewis \& Maslin, 2015). The detrimental effects of anthropogenic pollutants such as nutrients, chemicals, and sediment entering the environment via industrial effluents and agricultural runoff are well known, but the release of microplastics (MP) is of increasing concern (Browne, Galloway \& Thompson, 2007; Thompson et al., 2015; Waller et al., 2017). Microplastics are defined as any plastic particle that is between $100 \mathrm{~nm}$ and $5 \mathrm{~mm}$ in size and include spheres, pellets, fibers and other small plastics commonly used in cosmetics, clothing, pharmaceuticals and industrial products (Zitko \& Hanlon, 1991; Thompson et al., 2004; Betts, 2008; Arthur, Baker \& Bamford, 2009; Koelmans et al., 2015). They can be introduced to the environment via sewage, wastewater treatment effluents, industrial spills and runoff, and via the fragmentation of larger plastics (Browne et al., 2011; Cole et al., 2011; Conley et al., 2019). The progressive fragmentation of MP and their dynamic position in the water column due to wave action may impact planktonic, nektonic, and benthic organisms directly (Browne, Galloway \& Thompson, 2007; Browne et al., 2008; Thompson et al., 2009; Wright, Thompson \& Galloway, 2013). In addition, organisms encountering or consuming MP may be exposed to organic pollutants, heavy metals and pathogenic microbes bound to their surfaces (Mato et al., 2001; Hirai et al., 2011; Zettler, Mincer \& Amaral-Zettler, 2013; Lamb et al., 2018; Rotjan et al., 2019; Dudek et al., 2020). Much of the existing research on MP ingestion has revolved around vertebrates, with fish being the most studied group of aquatic organisms (de Sá et al., 2018). Studies that investigate MP ingestion by marine invertebrates are of mounting importance if we are to better understand the overall impact of MP in the marine world (Wright, Thompson \& Galloway, 2013; de Sá et 
al., 2018). Marine ciliates (Christaki et al., 1998), calanoid copepods (Wilson, 1973), amphipods (Thompson et al., 2004), lugworms (Thompson et al., 2004), blue mussels (Ward \& Targett, 1989; Ward, Levinton \& Shumway, 2003; Browne et al., 2008; Ward \& Kach, 2009), Pacific oysters (Sussarellu et al., 2015), sea cucumbers (Graham \& Thompson, 2009), sea anemones (Morais et al., 2020), corals (Hall et al., 2015; Allen, Seymour \& Rittschof, 2017; Rotjan et al., 2019), lobsters (Murray \& Cowie, 2011) and the larvae of several invertebrate phyla (Hart, 1991) have been known to ingest MP in laboratory settings, and many ingest MP in situ. Several of these taxa exhibit some ability to select particles based on size or type, and some can defecate, regurgitate or otherwise egest the particles (Zebe \& Schiedek, 1996; Wilson, 1973; Powell \& Berry, 1990; Thompson et al., 2004; Graham \& Thompson, 2009; Sussarellu et al., 2015; Hankins, Duffy \& Drisco, 2018; Rotjan et al., 2019). Detrimental effects of MP ingestion by these animals include tissue inflammation, neurotoxicity, energy depletion, reduced skeletal growth rates, increased stress, and reduced immune function, feeding and reproduction (Besseling et al., 2013; von Moos, Burkhardt-Holm \& Köhler, 2012; Avio et al., 2015; Cole et al., 2015; Sussarellu et al., 2015; Chapron et al., 2018; Hankins, Duffy \& Drisco, 2018; Reichert et al., 2018; Tang et al., 2018; Rotjan et al., 2019). However, these impacts are highly variable across species, suggesting that some invertebrates may be more vulnerable to MP ingestion than others.

Sponges (Phylum Porifera) are particularly understudied in MP research, despite the fact that they are globally distributed across benthic ecosystems (van Soest et al., 2012; de Sá et al., 2018). Sponges are geographically and spatially cosmopolitan and occur in shallow-water reefs, deep-water habitats, hydrothermal vents, artic waters, and in many freshwater systems (Hooper \& van Soest, 2012). Sponges often exhibit high pumping rates $\left(0.005-0.6 \mathrm{~L}\right.$ of seawater s${ }^{-1} \mathrm{~L}^{-1}$ of 
99 sponge tissue) and can therefore process large volumes of seawater through their canals and 100 greater aquiferous systems (Reiswig, 1974; McMurray, Pawlik \& Finelli, 2014; Pawlik, Loh \& 101 McMurray, 2018). In fact, sponge communities may overturn the water column (up to $30 \mathrm{~m}$ 102 deep) every 1-56 days (Pile, Patterson \& Witman, 1996; Savarese et al., 1997; McMurray, 103 Pawlik \& Finelli, 2014; Pawlik, Loh \& McMurray, 2018). As marine sponges draw seawater 104 through their systems of internal canals and chambers, they retain food particles including 105 diatoms, cyanobacteria, viruses, flagellates, ciliates and yeast cells (Reiswig, 1971/1974/1975/1990; Frost, 1978; Imsiecke, 1993; Pile, Patterson \& Witman, 1996; Pile et al., 1997; Ribes, Coma \& Gili, 1999; Kowalke, 2000; Hadas et al., 2006; Maldonado et al., 2010). These food particles are typically smaller than $70 \mu \mathrm{m}$ in diameter (Ribes, Coma \& Gili, 1999) because sponge ostia (exterior, incurrent openings) rarely exceed $60 \mu \mathrm{m}$ and typically prohibit particles greater than $50 \mu \mathrm{m}$ from entering the sponge (Reiswig, 1971; Simpson, 1984). The removal of these food particles from the water column by sponges plays an essential role in nutrient cycling on coral reefs (Lesser, 2006; van Soest et al., 2012; de Goeij et al., 2013; Pawlik, Burkepile \& Thurber, 2016; de Goeij et al., 2017). Importantly, as sponges increase their dominance on many coral reefs, their influence on overall reef function may become amplified (Zea, 1993; McMurray, Henkel \& Pawlik, 2010; Colvard \& Edmunds, 2011; Villamizar et al., 2013). Their widespread distribution, ability to retain small particles, and their prolific seawater

117 filtering make sponges ideal candidates for evaluating MP abundance in marine systems.

Few studies have examined MP ingestion by sponges. One laboratory study exposed the temperate sponges Tethya bergquistae Hooper \& Wiedenmayer (1994) and Crella incrustans sponge respiration or food particle retention (Baird, 2016). The study concluded that sponges 
122 may be resistant to MP exposure. Other laboratory studies have used plastic beads $(0.1,0.2,0.5$,

$1231.0,4.0$ and $5.7 \mu \mathrm{m}$ in diameter) to study sponge physiology and have demonstrated the uptake

124 of the beads in sponge tissues (Willenz \& Van de Vyver, 1982; Turon, Galera \& Uriz, 1997;

125 Leys \& Eerkes-Medrano, 2006). Recently, Girard et al. (2021) examined the presence,

126 abundance and diversity of microparticulate pollutants in tropical sponges from North Sulawesi,

127 Indonesia. They found that sponges do take up foreign particles, including MP such as

128 polystyrene, and incorporate them into their skeletons and other internal tissues (Girard et al.,

129 2021). The authors reported a maximum concentration of 612 foreign particles $\mathrm{g}^{-1}$ of dry sponge

130 tissue, and concluded that sponges may act as bioindicators of marine microparticulate pollutants

131 (Girard et., 2021). Modica, Lanuza \& García-Castrillo (2020) also recently found microfibers

132 embedded on the surfaces of preserved museum sponge specimens representing 31 families. The

133 authors predicted that the sponges, originally collected off the northern coast of Spain, were

134 actively collecting fibers from the surrounding seawater and had been doing so for over 20 years

135 (Modica, Lanuza \& García-Castrillo, 2020).

136 Microplastics have been detected in the Caribbean and sponges there are likely exposed

137 to these contaminants. Bosker, Guaita \& Behrens (2018) found an average of $261 \mathrm{MP} \mathrm{kg}^{-1} \mathrm{of}$

138 sediment on four Lesser Antilles beaches while Acosta-Coley et al. (2019) found over 100

139 particles $\mathrm{m}^{-2}$ on some Colombian beaches. Garcés-Ordóñez et al. (2019) found up to 2,863 MP

$140 \mathrm{~kg}^{-1}$ of dry soil in polluted mangrove forests in Colombia while Rose \& Webber (2019) found up

141 to $0.00573 \mathrm{MP} \mathrm{L}^{-1}$ in surface seawater in the heavily polluted Kingston Harbor of Jamaica.

142 However, surface measurements may seriously underestimate MP abundance (Gallo et al.,

143 2018). For example, it is estimated that about one twelfth of the total number of MP present in

144 the ocean ends up on the surface, with about the same fraction occurring in subsurface seawater 
145 and the rest occurring on the seafloor and on beaches (Andrady et al., 2011). Wright, Thompson

$146 \&$ Galloway (2013) also noted that benthic suspension and deposit feeders may be exposed to

147 biofouled and other high-density MP that sink to the benthos. Sponges are particularly abundant

148 on Caribbean reefs with a high biomass, species diversity, and a percent cover that exceeds that

149 of reef-building corals (Loh \& Pawlik, 2014; Easson et al., 2015; de Bakker et al., 2017; Pawlik,

150 Loh \& McMurray, 2018). Many Caribbean sponges feed heterotrophically on particulate organic

151 matter (POM) that is within the size range $(<5 \mathrm{~mm})$ of MP (McMurray et al., 2016; Rix et al.,

152 2016). Together, these studies suggest that Caribbean sponge communities are likely exposed to 153 MP pollution close to the benthos.

154 This study is the first to investigate the presence of potential MP (PMP) in Caribbean

155 sponges from Bocas del Toro, Panamá and to report a subsurface PMP concentration in

156 Caribbean seawater. We predicted that Saigon Bay, a heavily-impacted area in the Bocas del

157 Toro archipelago, would be polluted with MP. We further predicted that marine sponges in the

158 bay would be collecting these particles via filter feeding because sponges select food that is very

159 small $(<70 \mu \mathrm{m})$ and within the size range for particles considered to be MP $(100 \mathrm{~nm}-5000 \mu \mathrm{m})$.

160 We used fluorescence microscopy to identify and quantify PMP. Additional identifying

161 techniques such as FT-IR and Raman spectroscopy were not used because such technology was

162 not available at the time of study. As such, our results represent only a survey of PMP (as per

163 Covernton et al., 2019) in sponges from Bocas del Toro, and future studies should use chemical

164 analysis to confirm the presence of MP in sponges. Still, we report the occurrence of PMP in six 165 tropical sponge species and in seawater from Panamá and address the ecological implications of 166 our findings. 
168 Materials \& Methods

169 Study site and sample collection

170 Sponge and seawater samples were collected from Saigon Bay near Isla Colón, Bocas del Toro,

171 Panamá (Fig. 1). Collection and export permits were approved by the Ministry of Environment

172 of Panama (Research and Collections Permit No. SC/A-8-19 and Export Permit No. SEX/AO-1-

173 2019). Saigon Bay sits immediately adjacent to houses, hotels and docks and is susceptible to

174 anthropogenic pollution (Collin, 2005; Gochfeld, Schloder \& Thacker, 2007; Easson et al., 2015;

175 Fig. 1). The bay experiences a large degree of boat traffic, which may bring pollutants from other

176 parts of the archipelago into the area. Bocas del Toro has an underdeveloped waste disposal

177 infrastructure (Aronson et al., 2004; Carruthers et al., 2005; Gochfeld, Schloder \& Thacker,

178 2007; Easson et al., 2015). With heavy and frequent rains (3-5 m per year), much of this waste

179 enters the surrounding waterways via runoff and some is even observed floating in the area

180 (Caruthers et al., 2005; Collin et al., 2005; Kaufmann \& Thompson, 2005; Gochfeld, Schloder \&

181 Thacker, 2007; Easson et al., 2015; B. Fallon, 2019, pers. obs.).

182

Sponge samples were collected on 21 June 2019 from $\sim 6-8 \mathrm{~m}$ below the surface during

an outbound tide so that any pollutants concentrated near the developed area were likely pulled

through the bay (Fig. 1). A small ( $\sim 5-8 \mathrm{~cm} ; 0.08-1.0 \mathrm{~g}$ dry mass) section of sponge was

removed by hand or by steel blade from three individuals ( $\mathrm{N}=3$ replicates) of each of the six

study species: Aplysina cauliformis Carter (1882), Amphimedon compressa Duchassaing de

Fonbressin \& Michelotti (1864), Callyspongia vaginalis Lamarck (1814), Ircinia campana

Lamarck (1814), Mycale laevis Carter (1882) and Niphates erecta Duchassaing de Fonbressin \& 
191 Each sponge section was wrapped in aluminum foil underwater and placed in a mesh bag for 192 transport.

Four liters of seawater were collected at the same time and depth as the sponge samples.

194 Four, clean (washed with soap and water and rinsed three times with MilliQ®) 1 L glass jars

195

196

197

198

199

200

201

202

203

204

205

206

207

208

209

210

211

212

213

were covered in foil and sealed with metal lids before descent. The jars were opened and filled at depth, and then re-covered with foil and sealed. This was replicated twice more on 1 July and 6 July 2019 at the same site during outbound tides. A total of three seawater samples ( 4 L each) were obtained for this study. It should be noted that $\sim 100-200 \mathrm{~mL}$ of seawater occasionally leaked from one of the glass jars. Thus, the total volume of seawater filtered for the seawater samples was between 3.6 and 4.0 L. Counts were normalized to seawater sample volume for quantification of PMP concentrations.

\section{Sample processing}

Seawater samples $(\mathrm{N}=3)$ were processed separately on or close to their respective collection days (21 June, 1 July and 6 July 2019). Seawater ( 4 L) was vacuum filtered onto a pre-combusted $\left(450^{\circ} \mathrm{C}\right.$ for $\left.4 \mathrm{hr}\right) 0.7 \mu \mathrm{m}$ pore size $\left(\right.$ Whatman $\left.{ }^{\mathrm{TM}} 1825-047 \mathrm{GF} / \mathrm{F}\right)$ glass microfiber filter. The four glass jars and sides of the filtration funnel were rinsed with analytical grade water (MilliQ®) and this excess water $(\sim 100 \mathrm{~mL})$ was also filtered to maximize sample transfer. Seawater sample filters were then covered with another pre-combusted filter, wrapped in foil and stored at $-20^{\circ} \mathrm{C}$ until further analysis. Any PMP later found on the cover filters were added to the total number of PMP recorded for its corresponding seawater sample filter. A procedural blank was run in parallel to each of the three seawater samples, generating three MilliQ blanks (i.e., $\sim 1 \mathrm{~L}$ of MilliQ was added to a clean beaker, filtered, and the filter was stored at $-20^{\circ} \mathrm{C}$ ). 

approximately half using a steel utility blade: one half for preliminary analysis and methods development and the other half for final analysis. Each half was rinsed thoroughly with MilliQ

217 (as we were only interested in PMP retained within the sponge body), weighed on a clean piece of foil, wrapped in foil and frozen at $-20^{\circ} \mathrm{C}$ until further analysis. The halves used for final PMP analysis were lyophilized and each sample was partitioned into three subsamples $(\sim 0.05-0.3 \mathrm{~g}$ dry) with a steel utility blade. Subsamples were used to minimize tissue digestion time and the dry mass of each subsample varied because sponge tissue density varied across species even though each original sponge sample was approximately equal in length $(\sim 2-4 \mathrm{~cm})$. Final PMP counts were normalized to subsample dry mass during data analysis. Each subsample was cut into pieces with a utility blade and added to a clean $20 \mathrm{ml}$ glass scintillation vial and covered with foil. In total, 54 subsamples were generated ( 6 species $\times 3$ replicates $\times 3$ subsamples $)$. Approximately 5-10 mL of household bleach (Clorox ${ }^{\circledR}, 6 \%$ sodium hypochlorite) was added to each scintillation vial to digest the organic tissue. Bleach was used because it rapidly digests sponge tissue and because it causes minimal physical degradation of plastic particles (Hooper, 2003; Collard et al., 2015). The bleach we used was not pre-filtered to remove potential plastic contaminants before use because the high viscosity of bleach slows filtering time considerably. Although, we now strongly recommend filtering bleach before use (see "Evaluation of methods and considerations"). Still, we used procedural blanks (see following paragraph) to evaluate the degree of pre-existing experimental contamination in our samples. Vials with sponge tissue and bleach were heated to $60^{\circ} \mathrm{C}$ for $2 \mathrm{hr}$ to expedite digestion (Conley et al., 2019; Payton, Beckingham \& Dustan, 2020). If necessary, additional bleach was added to the vials to digest any remaining tissue. 
After bleach digestion, each subsample $(\mathrm{N}=54)$ was filtered onto a pre-combusted $0.7 \mu \mathrm{m}$

238

pore size (Whatman ${ }^{\mathrm{TM}} 1825-047 \mathrm{GF} / \mathrm{F}$ ) glass microfiber filter. Approximately $5-10 \mathrm{~mL}$ of

MilliQ was added to the glass filtration funnel prior to the digested sponge subsample in order to minimize filtering time. After the sample was fully filtered, the sides of the funnel were rinsed with excess MilliQ to ensure maximum sample retention onto the filter. The filter was then removed and kept in a covered aluminum foil dish until further analysis. A total of six procedural blanks were run alongside the subsamples; approximately $10 \mathrm{~mL}$ of bleach was added to six clean scintillation vials, heated, and filtered.

\section{Positive controls}

Positive controls with known MP types were used to demonstrate plastic fluorescence behavior as well as the minimal effect of bleach and heat on that behavior. Microplastics were generated by cleaning common laboratory and consumer plastics (such as spray bottles, dish ware, monochromatic clothing, etc.) with 100\% isopropyl alcohol and shaving particles $(<5 \mathrm{~mm})$ into clean $20 \mathrm{~mL}$ glass scintillation vials using a steel utility blade. Plastic type was identified by the recycling label or clothing tag on each unit of plastic. Ten plastic types were used including high density polyethylene (HDPE), low density polyethylene (LDPE), polyethylene (PE), polyethylene terephthalate (PETE), polypropylene (PP), polystyrene (PS), polyvinyl chloride (PVC), unknown plastic (recycling label \#7) and the clothing fibers polyolefin and polyester (only clothes made with $100 \%$ polyolefin or polyester were sampled). Different colors of the same plastic type were collected when possible. Two scintillation vials were prepared for each plastic type: one for the addition of bleach and heat ( $\mathrm{N}=10$ vials) and another for the addition of MilliQ without heat ( $\mathrm{N}=10$ vials). Five to $10 \mathrm{~mL}$ of bleach was added to the first set of vials, 
260 which were then covered with foil and heated to $60^{\circ} \mathrm{C}$ for $2 \mathrm{hr}$. Additionally, 5-10 mL of MilliQ

261 was added to the other set of vials, which were then covered with foil and not heated. All

262 positive controls were filtered according to the sponge filtering procedure.

263

264

PMP visualization

265

266

267

268

269

270

271

272

273

274
All filters were analyzed for PMP presence using an E600 Nikon Eclipse fluorescence microscope fitted with a UV-1A fluorescence filter block (EX 360-370, DM 400, BA 400).

Potential MP was distinguished from fluorescing background material (inorganic sand grains, proteinaceous spongin, invertebrate cuticle fragments, etc.) based on the brightness and color of fluorescence (Figs. 2, S1). Each filter was mounted onto a microscope slide with a few drops of MilliQ to secure the filter onto the slide. The filter was then surveyed at $100 \times$ total magnification in a sweeping motion vertically and laterally until the entire filter was visually surveyed, and the number of detected PMP was recorded. Because the seawater sample filters were so concentrated with PMP, each filter and its corresponding MilliQ blank was surveyed independently three times. The first survey resulted in counts that were consistently much greater than those resulting from the second and third surveys, while the latter two surveys resulted in consistently similar counts. Therefore, we concluded that the elevated counts from survey 1 were a result of human error, and the mean number of PMP for each seawater and MilliQ blank filter was determined using only counts from the second and third surveys. A $10 \times 10 \mathrm{~mm}$ reticle net grid on one eyepiece in the microscope was used to measure the size of detected PMP. The size of nearly every PMP found in the sponge subsamples and corresponding blanks and the sizes of at least $15 \%$ of PMP found in the seawater samples and corresponding MilliQ blanks were recorded. The number and sizes of PMP in the positive controls were not recorded as they served only to

Peer) reviewing PDF | (2020:12:56751:2:0:NEW 23 May 2021) 
283 demonstrate plastic fluorescence behavior and the effect of bleach and heat on that behavior.

284 Only particles greater than or equal to $10 \mu \mathrm{m}$ in maximum length were recorded for any filter.

285 Particle sizes were categorized into nine groups based on maximum length: 10-20 $\mu \mathrm{m}, 21-50$

$286 \mu \mathrm{m}, 51-100 \mu \mathrm{m}, 101-300 \mu \mathrm{m}, 301-500 \mu \mathrm{m}, 501-1000 \mu \mathrm{m}, 1001-3000 \mu \mathrm{m}, 3001-5000 \mu \mathrm{m}$ and

$287>5000 \mu \mathrm{m}$. These size categories were chosen post hoc based on the sizes of the particles

288 detected on the filters. They serve to demonstrate the frequency of different particle sizes in all

289 samples and blanks, and to identify any differences in particle uptake or retention by sponges

290 based on particle size. Particle sizes are reported in a stacked bar chart (Fig. 3) and do not reflect

291 blank-corrected values (i.e., the proportion of particles within each size category represents the

292 percent of total particles surveyed and may reflect the sizes of potential contaminants). The

293 number of PMP on sponge and seawater sample filters was corrected based on the average

294 number of PMP found on the corresponding blank filters. These corrections were not done on the

295 basis of size (i.e., 10-20 $\mu \mathrm{m}$ particles in the blank were not subtracted from 10-20 $\mu \mathrm{m}$ particles

296 in the sample) as we aimed only to evaluate general background contamination. Occasionally,

297 this correction led to a negative value in some sponge subsamples, and in these cases, the PMP

298 value for the sponge subsample was adjusted to zero.

299

300 Mitigating contamination

301 Since plastic is abundant in field and laboratory settings, several steps were taken to minimize

302 sample contamination. Nitrile gloves and 100\% cotton cloths and lab coats were used at all times

303 during sample processing. However, it is possible that cotton fibers from these materials were

304 counted in blanks and samples because cotton (cellulose) may autofluoresce under UV light

305 (Malinowska et al., 2015). The particular fluorescence behavior of cotton cellulose under our 
306 microscopy conditions was not tested in this study. Glassware was used in place of plasticware

307 and all glassware and samples were covered with foil when not in use. Glassware and metal

308 utensils were cleaned with soap and water and rinsed three times with MilliQ before use. Lastly,

309 dry sponge samples were cut into scintillation vials under a laminar flow hood to reduce airborne

310 contamination. Though these steps were taken to minimize contamination, we recognize that

311 false positives are still possible.

312

\section{Data analysis}

314 Potential microplastic (PMP) concentrations are reported as number of PMP per liter (PMP L-1)

315 for seawater samples and number of PMP per gram of dry tissue (PMP g-1) for sponge samples.

316 The blank-corrected number of PMP $\mathrm{g}^{-1}$ was determined for each of the 54 subsamples

317 representing the six species. These 54 values were then grouped by replicate to produce a mean

318 number of PMP g-1 for each replicate. These true replicate values $(\mathrm{N}=3)$ were then grouped by

319 species to produce a mean number of PMP $\mathrm{g}^{-1}$ for each species. A one-way ANOVA test

320 followed by a Tukey's HSD pairwise multiple comparisons test was used in R (R Core Team,

321 2019) to determine any significant differences in mean PMP concentrations between the six

322 sponge species.

\section{Results}

\section{Plastic fluorescence behavior and positive controls}

326 Plastic particles fluoresced electric blue when exposed to UV light (except for red PP, which

327 fluoresced pink) and often fluoresced much brighter when compared to other materials (sand

328 grains, spongin, chitin, etc.), which had a blue-green and dulled fluorescence (Figs. 2, S1). Some 
329 plastic types (e.g., HDPE, PVC) showed weak to no fluorescence, while others (e.g., unknown

330 plastic with recycling label \#7, PETE, Polyester clothing fibers, PP) showed intermediate to

331 strong fluorescence (Fig. S1). Lightly colored plastics (e.g., clear, white, yellow, light blue, red)

332 fluoresced more often and stronger than darkly colored plastics (e.g., black, brown, gray, green,

333 dark blue), though some light plastics did not fluoresce at all (Fig. S1). Some plastics (i.e.,

334 unknown plastic with recycling label \#7) in the control MilliQ set showed small flecks of

335 fluorescent material even if the plastic itself did not fluoresce (Fig. S1G, H). Exposure to bleach

336 and heat did not impact plastic fluorescence behavior (Fig. S1).

337

338 Seawater

339 An average of $107 \pm 25 \mathrm{PMP} \mathrm{L}^{-1}$ was found in seawater samples collected from Saigon Bay. The 340 PMP detected in seawater varied in size, though very small $(10-20 \mu \mathrm{m})$ particles comprised $341 \sim 25 \%$ of the total number of particles detected (Fig. 3). The corresponding MilliQ blanks had 342 proportionately fewer very small particles $(\sim 16 \%)$, with $\sim 27 \%$ of all particles in the blanks being 343 101-300 $\mu \mathrm{m}$ in maximum length (Fig. 3). Although one large fiber $(3001-5000 \mu \mathrm{m})$ was found 344 in the seawater samples, no large fibers were found in the blanks, and no very large fibers, or 345 those that were $>5000 \mu \mathrm{m}$ and technically outside the range of MP, were found in the seawater 346 samples or MilliQ blanks. The number of particles detected in the MilliQ blanks (no more than 8 347 particles per filter) never exceeded $10 \%$ of those found in the samples, indicating that there was 348 minimal contamination during sample processing (Gago et al., 2016). 
351 The number of PMP $\mathrm{g}^{-1}$ of dry tissue varied across the six sponge species (one-way ANOVA,

$352 \mathrm{df}=5, \mathrm{~F}=5.358, \mathrm{p}=0.0081$; Fig. 4, Table 1). Callyspongia vaginalis, A. cauliformis, N. erecta and

353 I. campana showed the highest concentrations of particles (mean \pm SE $169 \pm 71,113 \pm 23,75 \pm 38$

354 and 71 $\pm 20 \mathrm{PMP} \mathrm{g}^{-1}$, respectively; Fig. 4), while $A$. compressa and M. laevis showed lower

355 concentrations (14 \pm 2 and $6 \pm 4 \mathrm{PMP} \mathrm{g}^{-1}$, respectively; Fig. 4). However, there were few

356 significant pairwise differences in mean PMP concentration between the six species (Fig. 4,

357 Table 1). The number of particles in the procedural blanks was sometimes greater than that in the

358 sponge subsamples themselves; seventeen of the 54 subsamples had a negative net number of

359 particles. As such, PMP counts in the sponge blanks as a percentage of counts in the sponge

360 subsamples sometimes exceeded $100 \%$. This finding is concerning because a blank percent of

$36110 \%$ has previously been used as a threshold to signify that sample counts are significantly

362 greater than blank counts (Gago et al., 2016). A relatively high level of background PMP in our

363 subsamples was likely the result of using non-filtered bleach and/or the use of very small

364 amounts of tissue ( $\sim 0.05-0.3 \mathrm{~g})$ for each subsample (see "Evaluation of methods and

365 considerations").

366 Potential MP found in the sponge samples and blanks were mostly very small (10-20

$367 \mu \mathrm{m})$ or small $(21-50 \mu \mathrm{m})$, and together comprised over half of the total number of PMP detected

368 in all sponge samples (52\%) and blanks (66\%) (Fig. 3). Larger particles (51-1000 $\mu \mathrm{m})$

369 comprised $35 \%$ of the total number of particles in all sponge samples, whereas they made up

$37025 \%$ of those found in the blanks (Fig. 3). Medium (1001-3000 $\mu \mathrm{m}$ ) fibers comprised 10\% and

$3719 \%$ of particles in the sponges and blanks, respectively. Large $(3001-5000 \mu \mathrm{m})$ and very large

372 fibers ( $>5000 \mu \mathrm{m}$; technically outside the range of MP) were occasionally ( $3 \%$ of all particles) 
373 found in the sponge samples (to the exclusion of $A$. compressa), but were never detected in the

374 blanks (Fig. 3).

375

376 Discussion

377 Potential microplastic in seawater

378 An average concentration of $107 \pm 25 \mathrm{PMP} \mathrm{L}^{-1}$ of seawater in Saigon Bay is striking. Few studies

379 have investigated MP concentrations in Caribbean seawater but reports of surface concentrations 380 have not exceeded 0.00573 $\mathrm{MP} \mathrm{L}^{-1}$ (Law et al., 2010; Rose \& Webber, 2019). These previous

381 studies targeted larger particles that were $>335 \mu \mathrm{m}$ and collected using plankton tows, while we 382 targeted smaller particles that were $>10 \mu \mathrm{m}$ and collected as bulk samples close to the benthos.

383 Surface MP concentrations in the world's coastal waters and oceans are also reported as lower 384 than ours, though these studies again targeted larger size fractions. Colton, Knapp \& Burns 385 (1974) reported a concentration of $0.000067 \mathrm{MP} \mathrm{L}^{-1}(>947 \mu \mathrm{m}$, plankton tows) in the open 386 northwest Atlantic Ocean while Doyle et al. (2011) reported a maximum of 0.00019 $\mathrm{MP} \mathrm{L}^{-1}$ 387 (>505 $\mu \mathrm{m}$, plankton tows) in the coastal northeast Pacific Ocean. Aliabad, Nassiri \& Kor (2019) 388 reported a maximum of $0.00114 \mathrm{MP} \mathrm{L}^{-1}(>333 \mu \mathrm{m}$, plankton tows) in the Gulf of Oman while 389 Payton, Beckingham \& Dustan (2020) reported a maximum of 0.6 MP L-1 (>43 $\mu \mathrm{m}$, grab 390 samples) in the estuarine Cooper River of South Carolina.

391 Recent findings suggest that previous studies significantly underestimate MP concentrations in seawater because plankton tow nets (300-1000 $\mu \mathrm{m}$ mesh) are commonly used 393 when sampling the upper $1 \mathrm{~m}$ of the water column (Covernton et al., 2019). Kang et al. (2015) 394 and Barrows et al. (2017) concluded that these tows allow smaller MP $(<300 \mu \mathrm{m})$ and fibers (due to their small width) to pass through holes in the nets, and that these studies may be 
396

397

398

399

400

401

402

403

404

405

406

407

408

409

410

411

412

413

414

415

416

417

418

underestimating seawater MP concentrations by orders of magnitude. Covernton et al. (2019)

compared the suitability of in situ sieve versus bulk sample methods to measure MP abundance

in seawater. They found that bulk seawater samples collected in $1 \mathrm{~L}$ glass jars and filtered

directly onto $8 \mu \mathrm{m}$ pore size filters resulted in PMP concentrations that were on average 8.5

times higher than samples that were collected in $10 \mathrm{~L}$ buckets, sieved using a $63 \mu \mathrm{m}$ mesh in the

field, and then filtered (Covernton et al., 2019). They concluded that studies using plankton nets

may underestimate MP concentrations by up to four orders of magnitude compared to studies

that target smaller $(<100 \mu \mathrm{m})$ plastics (Covernton et al., 2019). The authors emphasized the

necessity of using bulk seawater samples and sensitive filtration methods (ability to collect

plastics down to $10 \mu \mathrm{m}$ ) when assessing the exposure of marine organisms to MP pollution

(Covernton et al., 2019).

An average seawater concentration of $107 \mathrm{PMP} \mathrm{L}^{-1}$ in our study compares better with MP studies that used bulk samples and sensitive filtration methods. Covernton et al. (2019) reported 5.28 $\mathrm{PMP} \mathrm{L}^{-1}$ in filtered $(8 \mu \mathrm{m})$ surface seawater samples from coastal British Columbia,

Canada. Jiang et al. (2020) pumped surface seawater through $50 \mu \mathrm{m}$ net and reported $6.5 \mathrm{MP} \mathrm{L}^{-1}$ in the South Yellow Sea. Norén \& Naustvoll (2010) pumped surface seawater through a $10 \mu \mathrm{m}$

filter and reported $102 \mathrm{MP} \mathrm{L}^{-1}$ in Swedish coastal waters. Although our subsurface value of 107

PMP L-1 corroborates Norén \& Naustvoll (2010), comparisons with previous studies are difficult.

Our result reflects the presence of PMP in seawater from Saigon Bay, and future studies are needed to verify the presence of MP in this area using chemical analysis. Additionally, we sampled subsurface seawater and used different methods (grab samples filtered directly onto a $0.7 \mu \mathrm{m}$ filter) compared to these previous studies, so it is uncertain whether our seawater value is relatively high compared to reported values. As such, subsurface seawater must be evaluated at 
419 additional sites and across time in the Bocas del Toro archipelago to confirm an elevated level of

420 plastic contaminants in this area compared to previous reports. We recommend the continued use

421 of bulk samples and sensitive filtration, coupled with higher resolution techniques, to more

422 accurately identify and quantify MP particles in seawater.

423

424 Potential microplastic in sponges

425 This is the first study to evaluate the presence of MP in wild Caribbean sponges. Although we

426 used only fluorescence microscopy to quantify PMP within our sponge samples, our blank-

427 corrected values offer important insight into the potential for wild sponges to ingest plastic

428 particles. The abundance of PMP detected in our sponge samples (6-169 PMP g-1) compares

429 well with or was lower than that detected in a recent study. Girard et al. (2021) examined

430 microparticulate pollutants (including natural particles like minerals and shell fragments, as well

431 as anthropogenic particles like particulate cotton and polystyrene) in tropical sponges from

432 Indonesia. Like us, the authors used bleach-digested dried sponge subsamples $(0.0022-0.011 \mathrm{~g}$

433 dry) and vacuum-filtered them onto $1 \mu \mathrm{m}$ pore size membranes (Girard et al., 2021). Using

434 Raman spectroscopy, they detected 91-612 foreign particles $\mathrm{g}^{-1}$ (combination of natural and

435 man-made) ranging in size from 5 to $200 \mu \mathrm{m}$ in the sponge subsamples (Girard et al., 2021). Of

436 note was one sponge, Ircinia sp., which was found to have 159 polystyrene MP g-1 of dry tissue

437 (Girard et al., 2021). As such, our results (6-169 PMP g-1) align well with those of Girard et al.

438 (2021), especially considering that the PMP detected in our samples would only be a fraction of

439 the total particles detected in their samples. However, this comparison is limited as our results

440 indicate the presence of PMP in our sponge samples, whereas Girard et al. (2021) confirmed the

441 presence of MP in their samples using Raman spectroscopy.

Peer] reviewing PDF | (2020:12:56751:2:0:NEW 23 May 2021) 
443 PMP of the same size range made up only about one quarter of those found in seawater. This

444 suggests that the sponges we studied may demonstrate some selectivity in PMP ingestion,

445 preferring very small particles. This finding is not surprising considering that sponges typically

446 feed on microorganisms smaller than $70 \mu \mathrm{m}$ (Ribes, Coma \& Gili, 1999). Moreover, laboratory

447 studies have demonstrated the retention of microbeads $(<5.7 \mu \mathrm{m})$ in sponge tissues, which

448 supports the idea that sponges prefer very small particles (Schmidt, 1970; Willenz \& Van de

449 Vyver, 1982; Imsiecke, 1993). Still, a significant percent ( 35\%) of all particles (excluding

450 fibers) found in our sponge samples were between 51 and $1000 \mu \mathrm{m}$ in maximum length. Because

451 previous studies have demonstrated that sponges tend to ingest particles smaller than $50 \mu \mathrm{m}$

452 (Reiswig, 1971; Simpson, 1984), it is difficult to perceive at present the mechanism by which

453 such large particles may be entering sponge bodies. However, Cerrano et al. (2002) found that

454 exopinacocytes on the surface of some Indonesian sponges can endocytose particles as large as 2

$455 \mathrm{~mm}$ into the sponge body. Other studies have also documented endocytosis as an important

456 ingestion process in sponges (Willenz and van de Vyver 1982; Hammel \& Nickel 2014, Girard et

457 al., 2021), and new studies should continue to investigate potential uptake processes and confirm

458 the presence of such large particles in sponges.

459 A total of 20 large fibers $(3001 \mu \mathrm{m}$ to $>5000)$ were detected in the sponge samples but

460 they were absent in the blanks and present only once in the seawater samples. This finding

461 suggests that the sponges we sampled may concentrate synthetic fibers from seawater as they

462 filter feed. It is plausible that the fibers we detected were endocytosed from the ectosome by

463 action of exopinacocytes (Cerrano et al., 2002), or that they passed through the sponge ostia and

464 became stuck in the sponges' internal canals because fiber width, regardless of maximum length, 
465 never exceeded $10 \mu \mathrm{m}$. In addition, we rinsed the outside of our samples prior to analysis in an

466 attempt to isolate particles retained only within the sponge aquiferous system. Still, it is possible

467 that the fibers we detected were embedded on the surface of the sponges (Modica, Lanuza \&

468 García-Castrillo, 2020). It should also be noted that rinsing the sponge samples prior to analysis

469 may have removed particles from sponge oscula that were exiting the sponge body at the time of

470 collection, and future studies should consider this when evaluating particle egestion.

471 The location of PMP within the bodies of the six sponge species is unknown, but recent

472 studies have highlighted the presence of microparticulate pollutants in the ectosome (outer layer

473 of the sponge body), inner mesohyl, and around the choanocyte chambers of northern Atlantic

474 and western Pacific sponges (Modica, Lanuza \& García-Castrillo, 2020; Girard et al., 2021). The

475 latter study predicted that some particles were captured on the sponge surface by exopinacocytes

476 and were subsequently drawn into the body, while other particles were drawn passively into the

477 aquiferous system via ostia and were later phagocytized by choanocytes (Girard et al., 2021).

478 The authors also suggested that non-spiculate sponges tended to incorporate larger $(>50 \mu \mathrm{m})$

479 particles into their skeletons whereas spiculate sponges tended to incorporate smaller $(<50 \mu \mathrm{m})$

480 particles into their ectosome (Girard et al., 2021). We did not perform histological experiments

481 in our study and so cannot report the location of PMP within the tissues of our study species.

482 However, because we examined both non-spiculate (A. cauliformis and I. campana) and

483 spiculate (A. compressa, C. vaginalis, M. laevis and $N$. erecta) sponges, it is possible that these

484 species may be incorporating MP into their tissues in ways suggested by Girard et al. (2021).

485 Furthermore, the calcareous sponge Sycon coactum Urban (1906) has been shown to egest

486 microbeads (up to $1.0 \mu \mathrm{m}$ ) by action of choanocytes, which can engulf the beads and carry them

487 into excurrent chambers (Leys \& Eerkes-Medrano, 2006). The ability of additional sponge 
488 species to egest other particles like algal remnants, bacterial cells and sediment is also well

489 documented (Francis \& Poirrier, 1986; Imsiecke, 1993; Yahel et al., 2007, McGrath et al., 2017),

490 and demonstrates the potential for sponges to egest MP. However, the ability of our specific

491 sponge species to egest particles is unknown. Future work should use histological methods to

492 better understand how MP enter the sponge body, where they are being retained, and whether

493 more species can egest MP.

494 Variation in PMP concentration and composition across sponge species may relate to

495 differences in sponge morphology, physiology, and/or the availability of MP in seawater. Sponge

496 traits such as ostia/oscula diameter, tissue density, pumping rate, aquiferous system complexity,

497 and/or microbial abundance may impact MP uptake and retention because these traits impact the

498 volume and residence time of seawater processed by sponges, as well as the size of particles

499 allowed into the sponge body (Reiswig, 1974; Weisz, Lindquist \& Martens, 2008; Easson et al.,

500 2015). Interestingly, Girard et al. (2021) observed that particle incorporation by sponges was

501 independent of particle material. In other words, the authors suggested that the sponges would

502 take up particles based on what was available in the surrounding seawater, and that any

503 differences in the composition of incorporated particles between species depended only on

504 particle spatial variation (Girard et al., 2021). Similarly, Modica, Lanuza \& García-Castrillo

505 (2020) found that fiber abundance in sponge ectosomes was independent of sponge species,

506 habitat type and depth, and that fibers were likely ubiquitous in the surrounding seawater. Like

507 these previous studies, our results indicate that particle uptake (amount and size) is independent

508 of sponge species. There were few significant differences in mean PMP concentration between

509 our sponge species (Fig. 4, Table 1), suggesting that they showed no differences in their

510 susceptibility to PMP ingestion. Additionally, the size fractions of particles detected in our 
511 samples were approximately equal across all species (Fig. 3), indicating that one species did not

512 prefer particles of a particular size compared to another species. Thus, our findings support the

513 hypothesis that particle uptake and retention (amount and type) is independent of sponge species

514 (Modica, Lanuza \& García-Castrillo, 2020). Furthermore, because there is little detailed data

515 describing the morphological and physiological features of the specific sponge species we

516 studied (e.g., ostia/oscula size, tissue density, pumping rate, etc.), and because we did not

517 measure these parameters in our study, we cannot yet draw correlations between these

518 characteristics and any differences found in PMP loads. Future studies should aim to identify any

519 such relationships across ours and additional sponge species. Also, studies should compare MP

520 loads and types in samples collected from areas that are differentially impacted by MP pollution

521 to confirm whether loads in sponges depend on particle spatial variation.

522

\section{Ecological implications}

524 A relatively high concentration of PMP in seawater from Bocas del Toro indicates that marine

525 life in the area may be exposed to MP. The archipelago is home to numerous marine invertebrate

526 species and many commercial and non-commercial fishes (Collin, 2005; Seemann et al., 2014).

527 High PMP concentrations in the archipelago's coastal waters suggests that these local species

528 may be susceptible to MP ingestion. This risk will likely be exacerbated as tourism and residency

529 rates continue to climb (Easson et al., 2015; World Bank, 2018; Dorsett \& Rubio-Cisneros, 530 2019).

531 Scaling our data to appreciable values helps to illuminate the story of PMP in sponges

532 collected from a heavily impacted reef in Bocas del Toro. An average concentration of 87 PMP

$533 \mathrm{~g}^{-1}$ across all sponge species in this study equates to $>8,000$ PMP particles in a sponge that 
534 weighs $100 \mathrm{~g}$ (dry), or a sponge that is approximately 1.5 L (McMurray, Blum \& Pawlik, 2008;

535 Girard et al., 2021). This number agrees well with that reported by Girard et al. (2021) who

536 predicted that at least 10,000 microparticulates (sum of MP, minerals, etc.) per sponge may exist

537 in some demosponges (100 g dry) from Indonesia. Furthermore, using known pumping rates

538 ( 0.09-0.48 $\left.\mathrm{L} \mathrm{sec}^{-1} \mathrm{~L}^{-1}\right)$ and tissue densities $\left(\sim 89-155 \mathrm{~g} \mathrm{~L}^{-1}\right)$ for sponges that are congeneric with

539 our species (Weisz, Lindquist \& Martens, 2008; Fiore, Freeman \& Kujawinski, 2017; Pawlik,

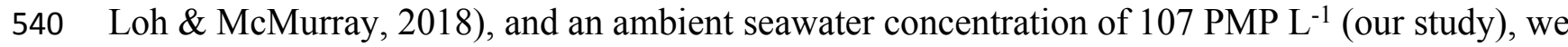

541 would predict that a $100 \mathrm{~g}$ sponge could be passing between 25,000 and 174,000 particles

542 through its body every hour. These values are far greater than the 8,000 PMP we predict to be

543 present in a sponge at any given moment in time. This finding supports the hypothesis that the

544 sponges we studied have some capacity to resist MP ingestion and/or that they have some ability

545 to egest the particles.

546 Interestingly, despite the presence of PMP in every species, the sponges from which

547 samples were taken appeared to be healthy and functional, as they had open ostia, showed no

548 evidence of necrosis, and were large individuals. Based on this gross examination, we did not

549 detect an external effect of PMP ingestion in sponges from Saigon Bay. From laboratory

550 experiments, Baird (2016) also reported an absence of effect with MP exposure having little

551 impact on temperate sponge respiration. In addition, relatively low concentrations of PMP in

552 sponge tissue despite there being $\sim 107 \mathrm{PMP} \mathrm{L}^{-1}$ in seawater in Saigon Bay support the idea that

553 the tropical sponges have some capacity to resist and/or egest MP. As selective filter feeders,

554 perhaps sponges can adjust their pumping rates in response to pulses of MP, as sometimes occurs

555 with increased sediment load (Gerrodette \& Flechsig, 1979; Maldonado et al., 2010; McMurray

556 et al., 2016). Girard et al. (2021) suggested that sponges may act as bioindicators of general 
557 microparticulate pollutants, but our results indicate that marine sponges may be resistant

558 specifically to MP exposure and therefore may not be the best indicators of MP pollution.

559 Increased spatial and temporal sampling is needed to test the potential for sponges to act as

560 bioindicators of MP in aquatic environments.

561

562 Evaluation of methods and considerations

563 We acknowledge that the methods used in this study have some limitations. Only fluorescence

564 microscopy was used to identify and quantify suspected MP. The lack of secondary verification,

565 such as by Raman or FT-IR spectroscopy, requires us to refer to the particles detected as

566 potential microplastics (PMP) as per Covernton et al. (2019). The sole use of fluorescence

567 microscopy to identify PMP in our samples raises several concerns. Firstly, the lack of additional

568 verification methods means that the number of particles detected in our samples may be

569 positively skewed owing to false positives. However, Payton, Beckingham \& Dustan (2020)

570 noted that fewer MP in seawater samples were detected using fluorescence microscopy than

571 when using brightfield microscopy alone, indicating the potential also for some negative bias in

572 our results because we did not use brightfield microscopy. In our positive controls, we confirmed

573 that not all plastic types fluoresce under our microscopy conditions, and that there is variation in

574 fluorescence strength and color between plastic types. Since we only counted particles that

575 fluoresced strongly with an electric blue color (i.e., the fluorescence behavior of white and clear

576 fragments of PETE and PP), our results may reflect the presence of only particular plastic types

577 and therefore underestimate the true number of MP present in the sponge and seawater samples.

578 It is also possible that we counted non-plastic particles that also exhibited this fluorescence

579 behavior. We strongly recommend the use of additional verification methods in future studies to 
580 confirm the presence of MP in sponges and other organisms. Recently, fluorescence lifetime

581 imaging microscopy (FLIM) has been shown to confidently identify MP in biological samples

582 (Monteleone et al., 2021), and warrants consideration for future use in MP studies.

583 We also recognize that an appreciable number of particles were found in the blanks for

584 the sponge study, sometimes amounting to more than were found in the sponge subsamples

585 themselves. As such, we report the presence of PMP in sponges from Bocas del Toro with

586 caution. While the counts in the MilliQ blanks as a percentage of counts in the seawater samples

587 was low $(<10 \%)$, MilliQ blanks were not digested with bleach. This suggests that MP present in

588 commercial bleach may have created a higher PMP background level in our sponge subsamples.

589 This background contamination would likely be reduced by pre-filtering the bleach solution, and

590 furthermore it's contribution to sample counts would be diminished if larger dry tissue

591 subsamples ( $>0.3$ g dry) were analyzed. As such, our study highlights the necessity in filtering

592 all solutions before use in MP studies. However, even if some of the PMP in the sponge samples

593 are artifacts of PMP in bleach, it is most striking how few particles were detected in the sponge

594 samples compared to the high load that was detected in the surrounding seawater, especially

595 considering that sponges process such large volumes of water as they filter feed.

596

Finally, the digestion method used in this study offers an efficient and cost-effective way

597 to survey marine sponges for the presence of PMP. The use of bleach with heat to digest organic

598 material showed no impact on the physical integrity or fluorescence behavior of plastic particles.

599 This digestion method also agrees with Collard et al. (2015) and other recent studies (J. Lynch,

600 2019, pers. comm.) and we recommend its use in future MP studies, with the addition of a pre-

601 filtering step.

602 


\section{Conclusions}

604 This study surveys the occurrence of PMP in wild sponges and in subsurface seawater from 605 Bocas del Toro, Panamá. Digestion of dry tissue using household bleach is a time- and cost606 effective method for evaluating MP presence because it showed no effect on plastic physical 607 integrity or fluorescence behavior. We recommend this technique with some additional solution 608 preparation as potential background contamination in our sponge samples highlights the need to 609 filter bleach before use in MP work. Additionally, the use of only fluorescence microscopy to 610 identify and quantify PMP in our samples limits our ability to compare our results with those of

611 previous MP studies, and we strongly encourage the use of additional chemical analysis in future 612 work to confirm the identity of MP. Still, a PMP concentration of $\sim 107 \mathrm{PMP} \mathrm{L}^{-1}$ in subsurface 613 seawater from Saigon Bay reported in this study compares well with or is greater than previous 614 reports of MP that used bulk samples and sensitive filtration techniques (down to $10 \mu \mathrm{m}$ ). As 615 such, we recommend the continued use of these methods along with the use of subsurface 616 samples when evaluating the exposure of benthic filter-feeding organisms to MP. Our results 617 further indicate that sponges ingest PMP, and that the sponges we studied may preferentially 618 collect fibers and very small $(10-20 \mu \mathrm{m})$ particles. However, the occurrence of PMP (6-169 $619 \mathrm{PMP} \mathrm{g}^{-1}$ ) in tissue samples taken from seemingly healthy sponges was relatively low considering 620 the high level of PMP detected in seawater. This finding suggests that the sponges we studied 621 may be somewhat resistant to PMP ingestion and/or have some capacity to egest the particles.

622 Lastly, the presence of PMP in sponges and seawater from Saigon Bay suggests that marine life 623 may be exposed to MP in Bocas del Toro. This exposure is only expected to increase with a 624 growth in population and tourism. Our study highlights the lack of MP research in the Caribbean, 
625 and future work should aim to further evaluate the presence and impact of MP in this beloved 626 and highly-frequented region.

627

628 Acknowledgements

629 We would like to thank the Smithsonian Tropical Research Institute for lab space, field supplies 630 and boat access. We also thank the Hollings Marine Laboratory, College of Charleston, Grice

631 Marine Laboratory, M. Janech, A. Bland, P. Lee and N. Schanke for technical support, lab space 632 and supplies. Thanks to C. Easson, C. Fiore, D. Gonzalez, S. Czwalina, A. Stephens and J.

633 Thurnham for their assistance with sample collection. We also thank S. Czwalina for assistance 634 with sample processing and A. Parry for help with data analysis. Thanks to the editor J. Pawlik, 635 to the reviewer C. Motti, and to two anonymous reviewers for their constructive comments.

636 Finally, this research would not have been possible without the advice and guidance of B.

637 Beckingham, J. Lynch, L. Jonas, K. Dudek, C. Fiore, C. Easson, G. Lôbo-Hajdu, M. Janech, R. 638 Thacker and P. Dustan.

639

640 References

641 Acosta-Coley, I., M. Duran-Izquierdo, E. Rodriguez-Cavallo, J. Mercado-Camargo, D. Mendez642 Cuadro, and J. Olivero-Verbel. 2019. Quantification of microplastics along the Caribbean 643 Coastline of Colombia: Pollution profile and biological effects on Caenorhabditis 644 elegans. Marine Pollution Bulletin 146:574-583.

645 Aliabad, M.K., M. Nassiri, K. Kor. 2019. Microplastics in the surface seawaters of Chabahar

646 Bay, Gulf of Oman (Makran Coasts). Marine Pollution Bulletin 143:125-133. 
647 Allen, A.S., A.C. Seymour, and D. Rittschof. 2017 Chemoreception drives plastic consumption 648 in a hard coral. Marine Pollution Bulletin 124:198-205.

649 Andrady, A.L. 2011. Microplastics in the marine environment. Marine Pollution Bulletin $650 \quad 62(8): 1596-1605$.

651 Aronson, R., I. Macintyre, C. Wapnick, and M. O’Neill. 2004. Phase shifts, alternative states and 652 the unprecedented convergence of two reef systems. Ecology 85:1876-1891.

653 Arthur, C., J. Baker, and H. Bamford (eds.). 2009. Proceedings of the International Research 654 Workshop on the Occurrence, Effects and Fate of Microplastic Marine Debris. Sep. 9-

655 11, 2008. NOAA Technical Memorandum NOS-OR\&R-30.

Avio, C.G., S. Gorbi, M. Milan, M. Benedetti, D. Fattorini, G. d'Errico, M. Pauletto, L.

657

658

659

660

661

662

663

664

665

666

667

668

Bargelloni, and F. Regoli. 2015. Pollutants bioavailability and toxicological risk from microplastics to marine mussels. Environmental Pollution 198:211-222.

Baird, C.A. 2016. Measuring the effects of microplastics on sponges. M.S. Thesis, Victoria University of Wellington.

Barrows, A.P.W., C.A. Neumann, M.L. Berger, and S.D. Shaw. 2017. Grab vs. neuston tow net: a microplastic sampling performance comparison and possible advances in the field. Analytical Methods 9:1446-1453.

Besseling, B., A. Wegner, E.M. Foekema, M.J. Heuvel-Greve, and A.A. Koelmans. 2013. Effects of microplastic on fitness and PCB bioaccumulation by the lugworm Arenicola marina (L.) Environmental Science and Technology 47:593-600.

Betts, K. 2008. Why small plastic particles may pose a big problem in the oceans. Environmental Science and Technology 42(24):8995-8995. 
669 Bosker, T., L. Guaita, and P. Behrens. 2018. Microplastic pollution on Caribbean beaches in the 670 Lesser Antilles. Marine Pollution Bulletin 133:442-447.

671

672

673

674

675

676

677

678

679

680

681

682

683

684

685

686

687

688

689

690

Browne, M.A., A. Dissanayake, T.S. Galloway, D.M. Lowe, and R.C. Thompson. 2008. Ingested microscopic plastic translocates to the circulatory system of the mussel, Mytilus edulis (L.). Environmental Science and Technology 42(13):5026-5031.

Browne, M.A., P. Crump, S.J. Nivens, E. Teuten, A. Tonkin, T. Galloway, and R. Thompson. 2011. Accumulation of microplastics on shorelines worldwide: sources and sinks. Environmental Science and Technology 45(21):9175-9179.

Browne, M.A., T.S. Galloway, and R. Thompson. 2007. Microplastic - an emerging contaminant of potential concern? Integrated Environmental Assessment and Management 3:559-561.

Carruthers, T.J.B., P.A.G. Barnes, G.E. Jacome, and J.W. Fourqurean. 2005. Lagoon scale processes in a coastally influenced Caribbean system: implications for the seagrass Thalassia testudinum. Caribbean Journal of Science 41:441-455.

Carter, H.J. 1882. Some sponges from the West Indies and Acapulco in the Liverpool Free Museum described, with general and classificatory remarks. Annals and Magazine of Natural History 9(52):266-368.

Carter, H.J. 1885. Descriptions of sponges from the neighbourhood of Port Phillip Heads, South Australia. Annals and Magazine of Natural History 16(94):277-368.

Cerrano, C., G. Bavestrello, M. Boyer, B. Calcinai, L.T.X. Lalamentik, and M. Pansini. 2002. Psammobiontic sponges from the bunaken marine park (North Sulawesi, Indonesia): interactions with sediments. Proceedings of the 9th International Coral Reef Symposium $1: 279-282$. 
691 Chapron, L., E. Peru, A. Engler, J.F. Ghiglione, A.L. Meistertzheim, A.M. Pruski, A. Purser, G. 692 Vétion, P.E. Galand, and F. Lartaud. 2018. Macro- and microplastics affect cold-water 693 corals growth, feeding and behaviour. Scientific Reports 8:1-8.

694 Christaki, U., J.R. Dolan, S. Pelegri, and F. Rassoulzadegan. 1998. Consumption of 695 picoplankton-size particles by marine ciliates: effects of physiological state of the ciliate 696 and particle quality. Limnology and Oceanography 43:458-464.

697 Cole, M., P. Lindeque, C. Halsband, and T.S. Galloway. 2011. Microplastics as contaminants in 698 the marine environment: A review. Marine Pollution Bulletin 62:2588-2597.

699 Cole, M., P. Lindeque, C. Halsband, and T.S. Galloway. 2015. The impact of polystyrene 700

701 microplastics on feeding, function and fecundity in the marine copepod Calanus helgolandicus. Environmental Science and Technology 49:1130-1137.

702

703

704

Collard, F., B. Gilbert, G. Eppe, E. Parmentier, and K. Das. 2015. Detection of anthropogenic particles in fish stomachs: An isolation method adapted to identification by Raman spectroscopy. Archives of Environmental Contamination and Toxicology 69:331-339.

Collin, R. 2005. Ecological monitoring and biodiversity surveys at the Smithsonian Tropical Research Institute's Bocas del Toro Research Station. Caribbean Journal of Science 41(3):367-373.

Colton, J.B., F.D. Knapp, B.R. Burns. 1974. Plastic particles in surface waters of the Northwestern Atlantic. Science 185(4150):491-497.

Colvard, N.B., and P.J. Edmunds. 2011. Decadal-scale changes in abundance of nonscleractinian invertebrates on a Caribbean coral reef. Journal of Experimental Marine Biology and Ecology 397(2):153-160. 
713 Conley, K., A. Clum, J. Deepe, H. Lane, and B. Beckingham. 2019. Wastewater treatment plants

714 as a source of microplastics to an urban estuary: Removal efficiencies and loading per

$715 \quad$ capita over one year. Water Research X 3:100030.

716 Covernton, G.A., C.M. Pearce, H.J. Gurney-Smith, S.G. Chastain, P.S. Ross, J.F. Dower, and sampling technique in seawater studies with implications for ecological risk assessment. Science of the Total Environment 667:124-132.

Crutzen, P.J. 2002. Geology of mankind. Nature 415:23.

721

722

723

724

725

726

727

728

729

730

731

732

733

734

735

de Bakker, D.M., F.C. van Duyl, R.P.M. Bak, M.M. Nugues, G. Nieuwland, and E.H. Meesters. 2017. 40 years of benthic community change on the Caribbean reefs of Curaçao and Bonaire: the rise of slimy cyanobacterial mats. Coral Reefs 36(2):355-367.

de Goeij, J.M., M.P. Lesser, and J.R. Pawlik. 2017. Chapter 8: Nutrient fluxes and ecological functions of coral reef sponges in a changing ocean. In: Carballo, J.L., and J.J. Bell, eds. Climate Change, Ocean Acidification and Sponges. Cham: Springer Nature, 373-410.

de Goeij, J.M., D. Van Oevelen, M.J. Vermeij, R. Osinga, and J.J. Middelburg. 2013. Surviving in a marine desert: The sponge loop retains resources within coral reefs. Science 342:108-110.

de Sá, L.C., M. Oliveira, F. Ribeiro, T.L. Rocha, and M.N. Futter. 2018. Studies of the effects of microplastics on aquatic organisms: What do we know and where should we focus our efforts in the future? Science of the Total Environment 65:1029-1039.

Dorsett, N., and T. Rubio-Cisneros. 2019. Many tourists, few fishes: Using tourists' and locals' knowledge to assess seafood consumption on vulnerable waters of the archipelago of Bocas del Toro, Panamá. Tourism Management 74:290-296. 
736

737

738

739

740

741

742

743

744

745

746

747

748

749

750

751

752

753

754

755

756

Doyle, M.J., W. Watson, N.M. Bowlin, S.B. Sheavly. 2011. Plastic particles in coastal pelagic ecosystems of the Northeast Pacific Ocean. Marine Environmental Research 71:41-52.

Duchassaing de Fonbressin, P., and G. Michelotti. 1864. Spongiaires de la mer Caraibe.

Natuurkundige verhandelingen van de Hollandsche maatschappij der wetenschappen te Haarlem 21(2):1-124.

Dudek, K.L., B.N. Cruz, B. Polidoro, and S. Neuer. 2020. Microbial colonization of microplastics in the Caribbean Sea. Limnology and Oceanography Letters 5:5-17.

Easson, C.G., K.O. Matterson, C.J. Freeman, S.K. Archer, and R.W. Thacker. 2015. Variation in species diversity and functional traits of sponge communities near human populations in Bocas del Toro, Panamá. PeerJ 3:e1385.

Fiore, C.L., C.J. Freeman, and E.B. Kujawinski. 2017. Sponge exhalent seawater contains a unique chemical profile of dissolved organic matter. PeerJ 5:e2870.

Francis, J.C., and M.A. Poirrier. 1986. Particle uptake in two fresh-water sponge species, Ephydatia fluviatilis and Spongilla alba (Porifera: Spongillidae). Transactions of the American Microscopical Society 105(1):11-20.

Frost, T.M. 1978. In situ measurement of clearance rates for the freshwater sponge Spongilla lacustris. Limnology and Oceanography 23:1034-1039.

Gago, J., F. Galgani, T. Maes, and R.C. Thompson. 2016. Microplastics in seawater:

Recommendations from the Marine Strategy Framework Directive implementation process. Frontiers in Marine Science 3:219. 
757 Gallo, F., C. Fossi, R. Weber, D. Santillo, J. Sousa, I. Ingram, A. Nadal, and D. Romano. 2018.

758 Marine litter plastics and microplastics and their toxic chemicals components: the need

759 for urgent preventive measures. Environmental Sciences Europe 30:13.

760 Garcés-Ordóñez, O., V.A. Castillo-Olaya, A.F. Granados-Briceñoc, L.M.B. García, L.F.E. Díaz.

761 2019. Marine litter and microplastic pollution on mangrove soils of the Ciénaga Grande

762 de Santa Marta, Colombian Caribbean. Marine Pollution Bulletin 145:455-462.

763 Gerrodette, T., and Flechsig, A.O. 1979. Sediment-induced reduction in the pumping rate of the 764 tropical sponge Verongia lacunosa. Marine Biology 55:103-110.

765 Girard, E.B., A. Fuchs, M. Kaliwoda, M. Lasut, E. Ploetz, W.W. Schmahl, and G. Wörheide. 2021. Sponges as bioindicators for microparticulate pollutants? Environmental Pollution

768 268:115851.

Gochfeld, D.J., C. Schloder, R.W. Thacker. 2007. Sponge community structure and disease prevalence on coral reefs in Bocas del Toro, Panamá. In: Custodio, M.R., G. Lobo-Hajdu, E. Hajdu \& G. Muricy, eds. Porifera Research: Biodiversity, Innovation and Sustainability, Serie Livros 28. Rio De Janeiro: Museu Nacional, 335-343.

Graham, E.R., and J.T. Thompson. 2009. Deposit- and suspension-feeding sea cucumbers (Echinodermata) ingest plastic fragments. Journal of Experimental Marine Biology and Ecology 368(1):22-29.

Hadas, E., D. Marie, M. Shpigel, M. Ilan. 2006. Virus predation by sponges is a new nutrientflow pathway in coral reef food webs. Limnology and Oceanography 51:1458-1550.

Hall, N.M., K.L.E. Berry, L. Rintoul, M.O. Hoogenboom. 2015. Microplastic ingestion by scleractinian corals. Marine Biology 162:725-732. 
779 Hammel, J.U., and M. Nickel. 2014. A new flow-regulating cell type in the Demosponge Tethya

780

781

782

783

784

785

786

787

788

789

790

791

792

793

794

795

796

797

798

799

800

801

wilhelma - functional cellular anatomy of a leuconoid canal system. PloS One 9:e113153.

Hankins, C., A. Duffy, and K. Drisco. 2018. Scleractinian coral microplastic ingestion: potential calcification effects, size limits, and retention. Marine Pollution Bulletin 135:587-593.

Hart, M.W. 1991. Particle capture and the method of suspension feeding by echinoderm larvae. Biology Bulletin 180(1):12-27.

Hirai, H., H. Takada, Y. Ogata, R. Yamashita, K. Mizukawa, M. Saha, C. Kwan, C. Moore, H. Gray, D. Laursen, E.R. Zettler, J.W. Farrington, C.M. Reddy, E.E. Peacock, and M.W. Ward. 2011. Organic micropollutants in marine plastics debris from the open ocean and remote and urban beaches. Marine Pollution Bulletin 62(8):1683-1692.

Hooper, J.N.A. 2003. Methods of dealing with sponges in the laboratory and preparation for their identification. In: Hooper, J.N.A. 'Sponguide’. Guide to Sponge Collection and Identification. Queensland: Queensland Museum, 4-6.

Hooper, J.N.A., and F. Wiedenmayer. 1994. Porifera. In: Wells, A. ed. Zoological Catalogue of Australia. Volume 12. Melbourne: CSIRO, 442.

Hooper, J.N.A., and R.W.M. van Soest. (eds.) 2012. Systema Porifera: A guide to the classification of sponges. Volume 1. United States: Springer US.

Imsiecke, G. 1993. Ingestion, digestion, and egestion in Spongilla lacustris (Porifera, Spongillidae) after pulse feeding with Chlamydomonas reinhardtii (Volvocales). Zoomorphology 113:233-244.

Jiang, Y., Y. Zhao, X. Wang, F. Yang, M. Chen, and J. Wang. 2020. Characterization of microplastics in the surface seawater of the South Yellow Sea as affected by season. Science of the Total Environment 724:138375. 
802 Kang, J.-K., O.Y. Kwon, K.-W. Lee, Y.K. Song, and W.J. Shim. 2015. Marine neustonic 803 microplastics around the southeastern coast of Korea. Marine Pollution Bulletin 96(1-2):

804 $304-312$.

805 Kaufmann, K.W., and R.C. Thompson. 2005. Water temperature variation and the

806 meteorological and hydrographic environment of Bocas del Toro, Panamá. Caribbean Journal of Science 41:392-413.

808

809

810

811

812

813

814

815

816

817

818

819

820

821

822

823

Koelmans, A.A., E. Besseling, W.J. Shim. 2015. Nanoplastics in the aquatic environment. In: Bergmann, M., L. Gutow, and M. Klages, eds. Marine Anthropogenic Litter. Cham: Springer, 329-344.

Kowalke, J. 2000. Ecology and energetics of two Antarctic sponges. Journal of Experimental Marine Biology and Ecology 247:85-97.

Lamarck, J.-B. 1814. Sur les polypiers empâtés. Annales du Museum national d'Histoire naturelle 20:294-458.

Lamb, J.B., B.L. Willis, E.A. Fiorenza, C.S. Couch, R. Howard, D.N. Rader, J.D. True, L.A. Kelly, A. Ahmad, J. Jompa, C.D. Harvell. 2018. Plastic waste associated with disease on coral reefs. Science 359:460-462.

Law, K.L., S. Morét-Ferguson, N.A. Maximenko, G. Proskurowski, E.E. Peacock, J. Hafner, and C.M. Reddy. 2010. Plastic accumulation in the North Atlantic Subtropical Gyre. Science DOI:10.1126/science.1192321.

Lesser, M. P. 2006. Benthic-pelagic coupling on coral reefs: feeding and growth of Caribbean sponges. Journal of Experimental Marine Biology and Ecology 328:277-288.

Lewis, S., and M. Maslin. 2015. Defining the Anthropocene. Nature 519:171-180. 
824 Leys, S.P., and D.I. Eerkes-Medrano. 2006. Feeding in a calcareous sponge: particle uptake by 825 pseudopodia. Biological Bulletin 211:157-171.

826

827

828

829

830

831

832

833

834

835

836

837

838

Loh, T.-L., and J.R. Pawlik. 2014. Chemical defenses and resource trade-offs structure sponge communities on Caribbean coral reefs. PNAS 111(11):4151-4156.

Maldonado, M., X. Zhang, X. Cao, L. Xue, H. Cao, and W. Zhang. 2010 Selective feeding by sponges on pathogenic microbes: a reassessment of potential for abatement of microbial pollution. Marine Ecology Progress Series 403:75-89.

Malinowska, K.H., T. Rind, T. Verdorfer, H.E. Gaub, and M.A. Nash. 2015. Quantifying synergy, thermostability, and targeting of cellulolytic. Analytical Chemistry 87: $7133-7140$.

Mato, Y., T. Isobe, H. Takada, H. Kanehiro, C. Ohtake, and T. Kaminuma. 2001. Plastic resin pellets as a transport medium for toxic chemicals in the marine environment. Environmental Science and Technology 35(2):318-324.

McGrath, E.C., D.J. Smith, J. Jompa, and J.J. Bella. 2017. Adaptive mechanisms and physiological effects of suspended and settled sediment on barrel sponges. Journal of Experimental Marine Biology and Ecology 496:74-83.

McMurray, S.E., J.E. Blum, and J.R. Pawlik. 2008. Redwood of the reef: growth and age of the giant barrel sponge Xestospongia muta in the Florida Keys. Marine Biology 155:159171.

McMurray, S.E., J.R. Pawlik, and C.M. Finelli. 2014. Trait-mediated ecosystem impacts: how morphology and size affect pumping rates of the Caribbean giant barrel sponge. Aquatic Biology 23:1-13. 
846 McMurray, S.E., T.P. Henkel, and J.R. Pawlik. 2010. Demographics of increasing populations of 847 the giant barrel sponge Xestospongia muta in the Florida Keys. Ecology 91(2):560-570.

848 McMurray, S.E., Z.I. Johnson, D.E. Hunt, J.R. Pawlik, and C.M. Finelli. 2016. Selective feeding 849 by the giant barrel sponge enhances foraging efficiency. Limnology and Oceanography 850 61(4):1271-1286.

851

852

853 854 855

856

857

858

859

860

861

862

863

864

865

866

Modica, L., P. Lanuza, and G. García-Castrillo. 2020. Surrounded by microplastic, since when? Testing the feasibility of exploring past levels of plastic microfibre pollution using natural history museum collections. Marine Pollution Bulletin 151:110846.

Monteleone, A., F. Wenzel, H. Langhals, and D. Dietrich. 2021. New application for the identification and differentiation of microplastics based on fluorescence lifetime imaging microscopy (FLIM). Journal of Environmental Chemical Engineering 9(1):104769.

Morais, L.M.S., F. Sarti, D. Chelazzi, A. Cincinelli, T. Giarrizzo, and J.E. Martinelli Filho. 2020. The sea anemone Bunodosoma cangicum as a potential biomonitor for microplastics contamination on the Brazilian Amazon coast. Environmental Pollution 265:114817.

Murray, F., and P.R. Cowie. 2011. Plastic contamination in the decapod crustacean Nephrops norvegicus (Linnaeus, 1758). Marine Pollution Bulletin 62(6):1207-1217.

Norén, F., and L. Naustvoll. 2010. Survey of microscopic anthropogenic particles in Skagerrak. TA 2779:1-20.

Pawlik, J.R., D.E. Burkepile, and R.V. Thurber. 2016. A vicious circle? Altered carbon and nutrient cycling may explain the low resilience of Caribbean coral reefs. Bioscience $66: 470-476$. 
867 Pawlik, J.R., T.-L. Loh, and S.E. McMurray. 2018. A review of bottom-up vs. top-down control 868 of sponges on Caribbean fore-reefs: what's old, what's new, and future directions. PeerJ 869 $6: e 4343$.

870

871

872

873

874

875

876

877

878

Payton, T.G., B.A. Beckingham, and P. Dustan. 2020. Microplastic exposure to zooplankton at tidal fronts in Charleston Harbor, SC USA. Estuarine, Coastal and Shelf Science 232:106510.

Pile, A.J., M.R. Patterson, and J.D. Witman. 1996. In situ grazing on plankton $<10 \mu \mathrm{m}$ by the boreal sponge Mycale lingua. Marine Ecology Progress Series 141:95-102.

Pile, A.J., M.R. Patterson, M. Savarese, V.I. Chernykh, and V.A. Fialkov. 1997. Trophic effects of sponge feeding within Lake Baikal's Littoral zone. 2. Sponge abundance, diet, feeding efficiency, and carbon flux. Limnology and Oceanography 42:178-184.

Powell, M.D., and A.J. Berry. 1990. Ingestion and regurgitation of living and inert materials by the estuarine copepod Eurytemora affinis (Poppe) and the influence of salinity. Estuarine, Coastal and Shelf Science 31(6):763-773.

R Core Team. 2019. R: A language and environment for statistical computing. R Foundation for Statistical Computing. Vienna, Austria. https://www.R-project.org/.

Reichert, J., J. Schellenberg, P. Schubert, and T. Wilke. 2018. Responses of reef building corals to microplastic exposure. Environmental Pollution 237:955-960.

Reiswig, H.M. 1971. In situ pumping activities of tropical demospongiae. Marine Biology 9:3850.

Reiswig, H.M. 1974. Water transport, respiration and energetics of three tropical marine sponges. Journal of Experimental Marine Biology and Ecology 14:231-249. 
889 Reiswig, H.M. 1975. Bacteria as food for temperate-water marine sponges. Canadian Journal of $890 \quad$ Zoology 53:582-589.

891 Reiswig, H.M. 1990. In situ feeding in 2 shallow-water hexactinellid sponges. In: Rützler, K., ed. 893

894

895

896

897

898

899

900

901

902

903

904

905

906

907

908

909

910
892 New Perspectives in Sponge Biology. Washington: Smithsonian Institution Press, 504 510.

Ribes, M., R. Coma, and J.-M. Gili. 1999. Natural diet and grazing rate of the temperate sponge Dysidea avara (Demospongiae, Dendroceratida) throughout an annual cycle. Marine Ecology Progress Series 176:179-190.

Rix, L., J.M. de Goeij, C.E. Mueller, U. Struck, J.J. Middelburg, F.C. van Duyl, F.A. Al-Horani, C. Wild, M.S. Naumann, D. van Oevelen. 2016. Coral mucus fuels the sponge loop in warm- and cold-water coral reef ecosystems. Scientific Reports 6(1):18715.

Rose, D., and M. Webber. 2019. Characterization of microplastics in the surface waters of Kingston Harbour. Science of the Total Environment 664:753-760.

Rotjan, R.D., K.H. Sharp, A.E. Gauthier, R. Yelton, E.M.B. Lopez, J. Carilli, J.C. Kagan, and J. Urban-Rich. 2019. Patterns, dynamics and consequences of microplastic ingestion by the temperate coral, Astrangia poculata. Proceedings of the Royal Society B 286:20190726.

Savarese, M., M.R. Patterson, V.I. Chernykh, V.A. Fialkov. 1997. Trophic effects of sponge feeding within Lake Baikal's littoral zone. 1. In situ pumping rates. Limnology and Oceanography 42:171-178.

Simpson, T.L. 1984. The Cell Biology of Sponges: Springer.

Schmidt, I. 1970. Phagocytose et pinocytose chez les Spongillidae. Zeitschrift für vergleichende Physiologie 66:398-420.

Peer] reviewing PDF | (2020:12:56751:2:0:NEW 23 May 2021) 
911 Seemann, J., C.T. González, R. Carballo-Bolaños, K. Berry, G.A. Heiss, U. Struck, and R.R.

912

913

914

915

916

917

918

919

920

921

922

923

924

925

926

927

928

929

930

931

932

933
Leinfelder. 2014. Assessing the ecological effects of human impacts on coral reefs in Bocas del Toro, Panamá. Environmental Monitoring and Assessment 186:1747-1763.

Sussarellu, R., M. Suquet, Y. Thomas, C. Lambert, C. Fabioux, M.E.J. Pernet, N.L. Goïc, V. Quillien, C. Mingant, Y. Epelboin, C. Corporeau, J. Guyomarch, J. Robbens, I. PaulPont, P. Soudant, and A. Huvet. 2015. Oyster reproduction is affected by exposure to polystyrene microplastics. PNAS 113(9):2430-2435.

Tang, J., X. Ni, Z. Zhou, L. Wang, and S. Lin. 2018. Acute microplastic exposure raises stress response and suppresses detoxification and immune capacities in the scleractinian coral Pocillopora damicornis. Environmental Pollution 243:66-74.

The World Bank. (2018). Online database. https://data.worldbank.org/indicator/ST.INT.ARVL?locations=PA, Accessed date: 18 May 2020.

Thompson, R.C. 2015. Microplastics in the marine environment: Sources, consequences and solutions. In: Bergmann, M., L. Gutow, and M. Klages, eds. Marine Anthropogenic Litter. Cham: Springer, 185.

Thompson, R.C., C.J. Moore, F.S. vom Saal, S.H. Swan. 2009. Plastics, the environment and human health: current consensus and future trends. Philosophical Transactions of the Royal Society of London B: Biological Science 364(1526):2153-2166.

Thompson, R.C., Y. Olsen, R.P. Mitchell, A. Davis, S.J. Rowland, A.W.G. John, D. McGonigle, and A.E. Russell. 2004. Lost at sea: where is all the plastic? Science 304:838.

Turon, X., J. Galera, and M.J. Uriz. 1997. Clearance rates and aquiferous systems in two sponges with contrasting life-history strategies. Journal of Experimental Zoology 278:22-36.

Peer) reviewing PDF | (2020:12:56751:2:0:NEW 23 May 2021) 
934 Urban, F. 1906. Kalifornische Kalkschwämme. Archiv für Naturgeschichte 72(1):33-76.

935 van Soest, R.W.M., N. Boury-Esnault, J. Vacelet, M. Dohrmann, D. Erpenbeck, and N.J. De

936 Voogd. 2012. Global diversity of sponges (Porifera). PLoS ONE 7:e35105. doi:

$937 \quad 10.1371 /$ journal.pone.0035105.

938 Villamizar, E., M.C. Diaz, K. Rützler, and R. de Nobrega. 2013. Biodiversity, ecological

939 structure, and change in the sponge community of different geomorphological zones of

940 the barrier fore reef at Carrie Bow Cay, Belize. Marine Ecology

941 (Berlin):10.1111/maec.12099.

942 von Moos, N., P. Burkhardt-Holm, and A. Köhler. 2012. Uptake and effects of microplastics on

943 cells and tissue of the blue mussel Mytilus edulis L. after an experimental exposure.

$944 \quad$ Environmental Science and Technology 46:11327-11335.

945 Waller, C.L., H.J. Griffiths, C.M. Waluda, S.E. Thorpe, I. Loaiza, B. Moreno, C.O. Pacherres,

946 and K.A. Hughes. 2017. Microplastics in the Antarctic marine system: An emerging area

947 of research. Science of the Total Environment 598:220-227.

948 Ward, J.E., and D.J. Kach. 2009. Marine aggregates facilitate ingestion of nanoparticles by

949 suspension-feeding bivalves. Marine Environmental Research 68(3):137-142.

950 Ward, J.E., and N.M. Targett. 1989. Influence of marine microalgal metabolites on the feeding

951 behavior of the blue mussel Mytilus edulis. Marine Biology 101:313-321.

952 Ward, J.E., J.S. Levinton, and S.E. Shumway. 2003. Influence of diet on pre-ingestive particle

953 processing in bivalves: I: transport velocities on the ctenidium. Journal of Experimental 954 Marine Biology and Ecology 293(2):129-149.

955 Weisz, J.B., N. Lindquist, and C.S. Martens. 2008. Do associated microbial abundances impact 956 marine demosponge pumping rates and tissue densities? Oecologia 155:367-376. 
957 Willenz, P., and G. Van de Vyver. 1982. Endocytosis of latex beads by the exopinacoderm in the 958 fresh water sponge Ephydatia fluviatilis: an in vitro and in situ study in SEM and TEM. $959 \quad$ Journal of Ultrastructure Research 79:294 -306.

960 Wilson, D.S. 1973. Food size selection among copepods. Ecology 54(4):909-914.

961 Wright, S.L., R.C. Thompson, and T.S. Galloway. 2013. The physical impacts of microplastics 962 on marine organisms: a review. Environmental Pollution 178:483-492.

963 Yahel, G., F. Whitney, H.M. Reiswig, D.I. Eerkes-Medrano, and S.P. Leys. 2007. In situ feeding 964 and metabolism of glass sponges (Hexactinellida, Porifera) studied in a deep temperate 965 fjord with a remotely operated submersible. Limnology and Oceanography 52(1):428$966 \quad 440$.

967 Zalasiewicz, J., M. Williams, W. Steffen, P. Crutzen. 2010. The new world of the Anthropocene. 968 Environmental Science \& Technology 44:2228-2231.

969 Zea, S. 1993. Cover of sponges and other sessile organisms in rocky and coral reef habitats of 970 Santa Marta, Colombian Caribbean Sea. Caribbean Journal of Science 29:75-88.

971 Zebe, E., and D. Schiedek. 1996. The lugworm Arenicola marina: a model of physiological 972 adaptation to life in the intertidal sediments. Helgoland Marine Research 50(1):37-68.

973 Zettler, E.R., T.J. Mincer, and L.A. Amaral-Zettler. 2013 Life in the 'plastisphere': microbial $974 \quad$ communities on plastic marine debris. Environmental Science and Technology 47:7137$975 \quad 7146$.

976 Zitko, V., and M. Hanlon. 1991. Another source of pollution by plastics: Skin cleaners with 977 plastic scrubbers. Marine Pollution Bulletin 22:41-42. 


\section{Table $\mathbf{1}$ (on next page)}

Results from a Tukey's HSD pairwise multiple comparisons test of mean potential microplastic (PMP) abundance across sponge species in $R$ ( $R$ Core Team, 2019).

The six sponge species are Aplysina cauliformis, Amphimedon compressa, Callyspongia vaginalis, Ircinia campana, Mycale laevis and Niphates erecta and significant differences $(p<0.05)$ are boldfaced. 
1 Table 1. Results from a Tukey's HSD pairwise multiple comparisons test of mean potential 2 microplastic (PMP) abundance across sponge species in $\mathbf{R}$ ( $R$ Core Team, 2019). The six 3 sponge species are Aplysina cauliformis, Amphimedon compressa, Callyspongia vaginalis, 4 Ircinia campana, Mycale laevis and Niphates erecta and significant differences $(\mathrm{p}<0.05)$ are 5 boldfaced.

\begin{tabular}{|c|c|}
\hline Pairwise comparison & Adjusted p-value \\
\hline A. cauliformis - A. compressa & 0.1269 \\
\hline A. cauliformis - C. vaginalis & 0.9701 \\
\hline A. cauliformis - I. campana & 0.9291 \\
\hline A. cauliformis - M. laevis & $\mathbf{0 . 0 3 6 0}$ \\
\hline A. cauliformis - N. erecta & 0.8863 \\
\hline A. compressa - C. vaginalis & $\mathbf{0 . 0 3 6 5}$ \\
\hline A. compressa - I. campana & 0.4709 \\
\hline A. compressa - M. laevis & 0.9687 \\
\hline A. compressa - N. erecta & 0.5416 \\
\hline C. vaginalis - I. campana & 0.5608 \\
\hline C. vaginalis - M. laevis & $\mathbf{0 . 0 1 0 1}$ \\
\hline C. vaginalis - N. erecta & 0.4893 \\
\hline I. campana - M. laevis & 0.1661 \\
\hline I. campana - N. erecta & 0.9999 \\
\hline M. laevis $-N$. erecta & 0.2016 \\
\hline
\end{tabular}

6 


\section{Figure 1}

Map of Saigon Bay located off the coast of Isla Colón, the main island of the Bocas del Toro archipelago of Panamá.

The star indicates sample collection site. Note the high level of development on the northeastern border of Saigon Bay. Map data (c) 2020 CNES/Airbus (c) 2020 Europa Technologies (c) 2020 Google.

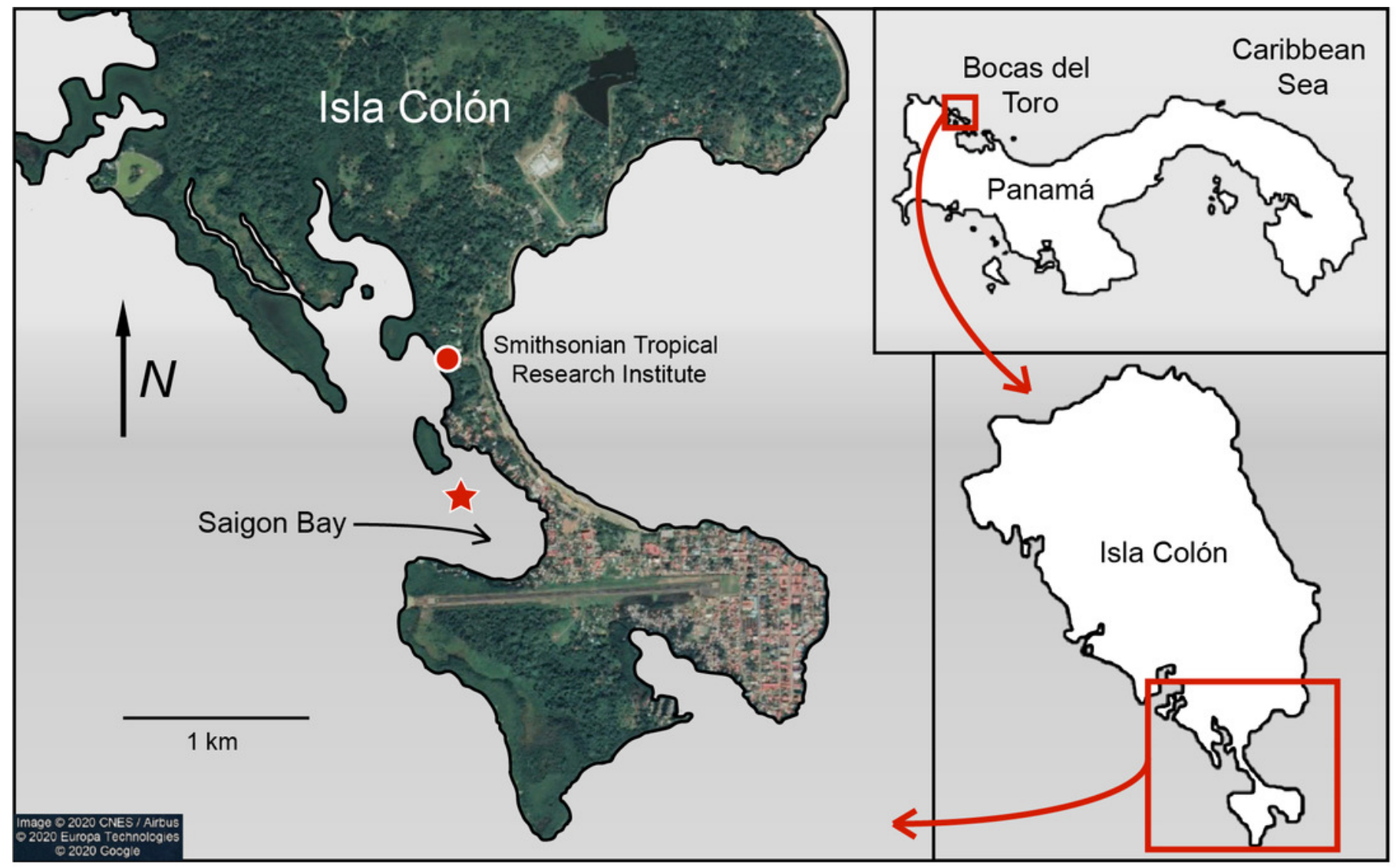




\section{Figure 2}

Potential microplastics (PMP) on the filters of sponge samples, seawater samples and blanks.

The top two rows include samples from the six sponge species: (A) A. cauliformis. (B) A. compressa. (C) C. vaginalis. (D) I. campana. (E) M. laevis. (F) N. erecta. The bottom two rows include seawater samples (G-J) as well as one MilliQ blank from the seawater study (K) and one blank from the sponge study (L). Note the dulled, blue-green autofluorescence (indicated by white arrows) of spongin fragments, sand grains and two copepods in images A, D, G and I, respectively, as it compares with the bright, electric blue autofluorescence (indicated by red arrows) of PMP. Images were taken at 100x total magnification and the scale bar shown in " $E$ " is applicable to all images. 


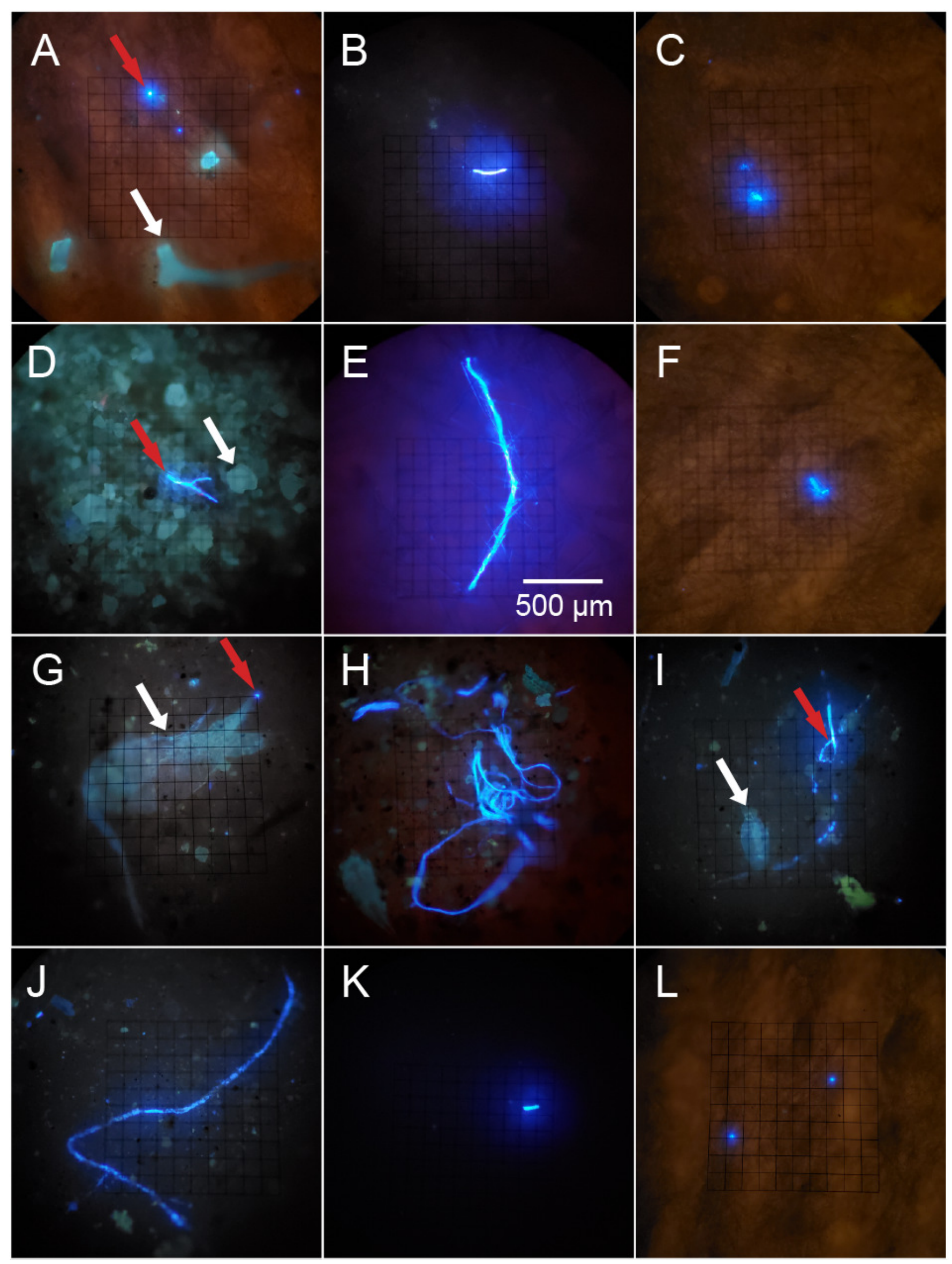


Figure 3

The relative abundance (percent of total) of potential microplastic (PMP) sizes detected in sponge and seawater samples and blanks.

Colors within the bars indicate the size of particles in micrometers $(\mu \mathrm{m})$. Note the presence of large (3001-5000 $\mu \mathrm{m})$ and very large $(>5000 \mu \mathrm{m})$ fibers only in some sponge samples.

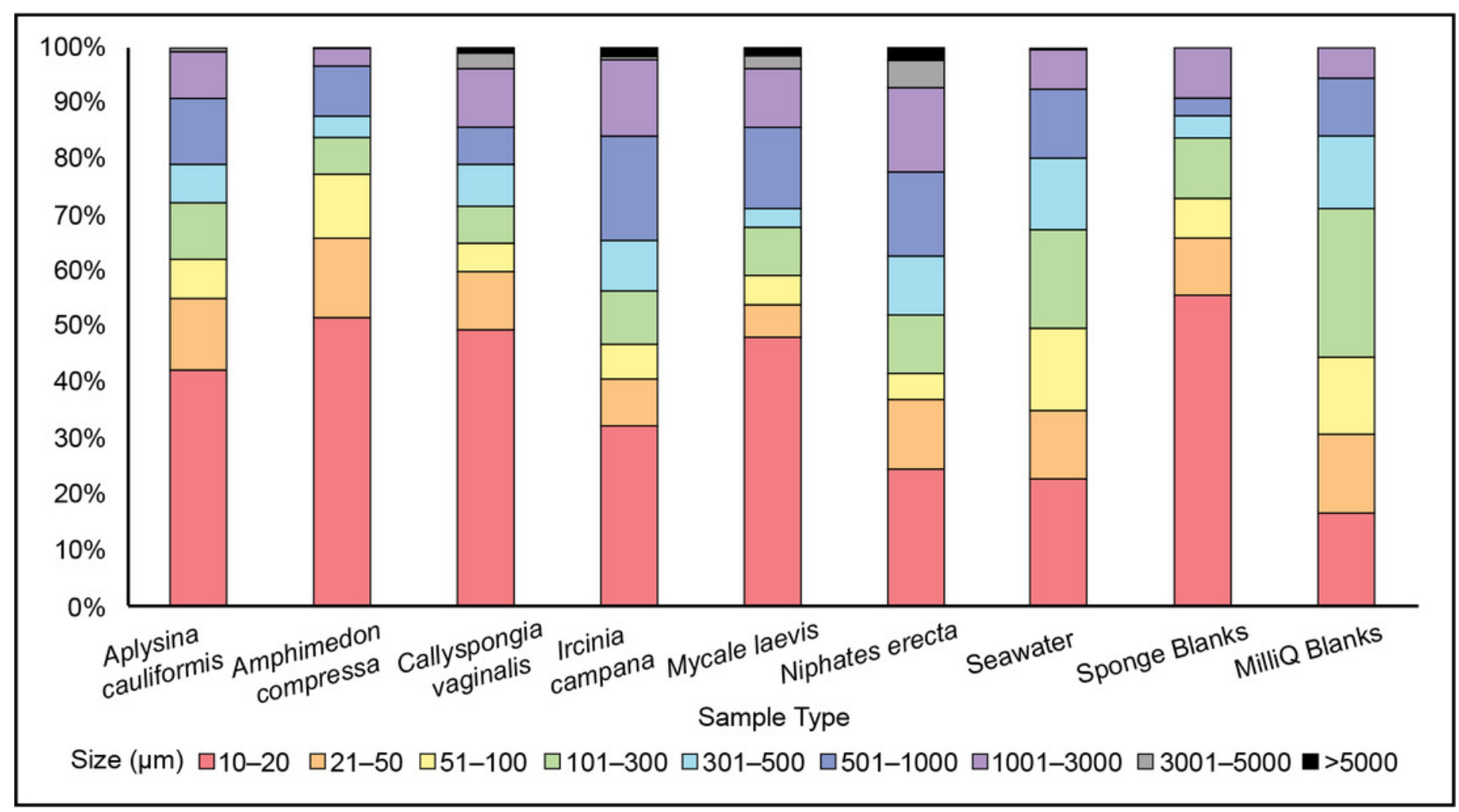


Figure 4

Number of potential microplastics (PMP) $\mathrm{g}^{-1}$ of dry sponge tissue.

Box plots ( $N=3$ replicates per species) are median inclusive and the " $\mathrm{x}$ " in each plot represents the mean. The mean number ( $\pm \mathrm{SE})$ of PMP $\mathrm{g}^{-1}$ of dry tissue for each species is listed below the sponge name. For reference, the mean number of PMP found in the seawater samples was $107 \pm 25$ particles $L^{-1}$. Letters above each plot indicate significant pairwise difference (Tukey's test, $\mathrm{p}<0.05$ ).

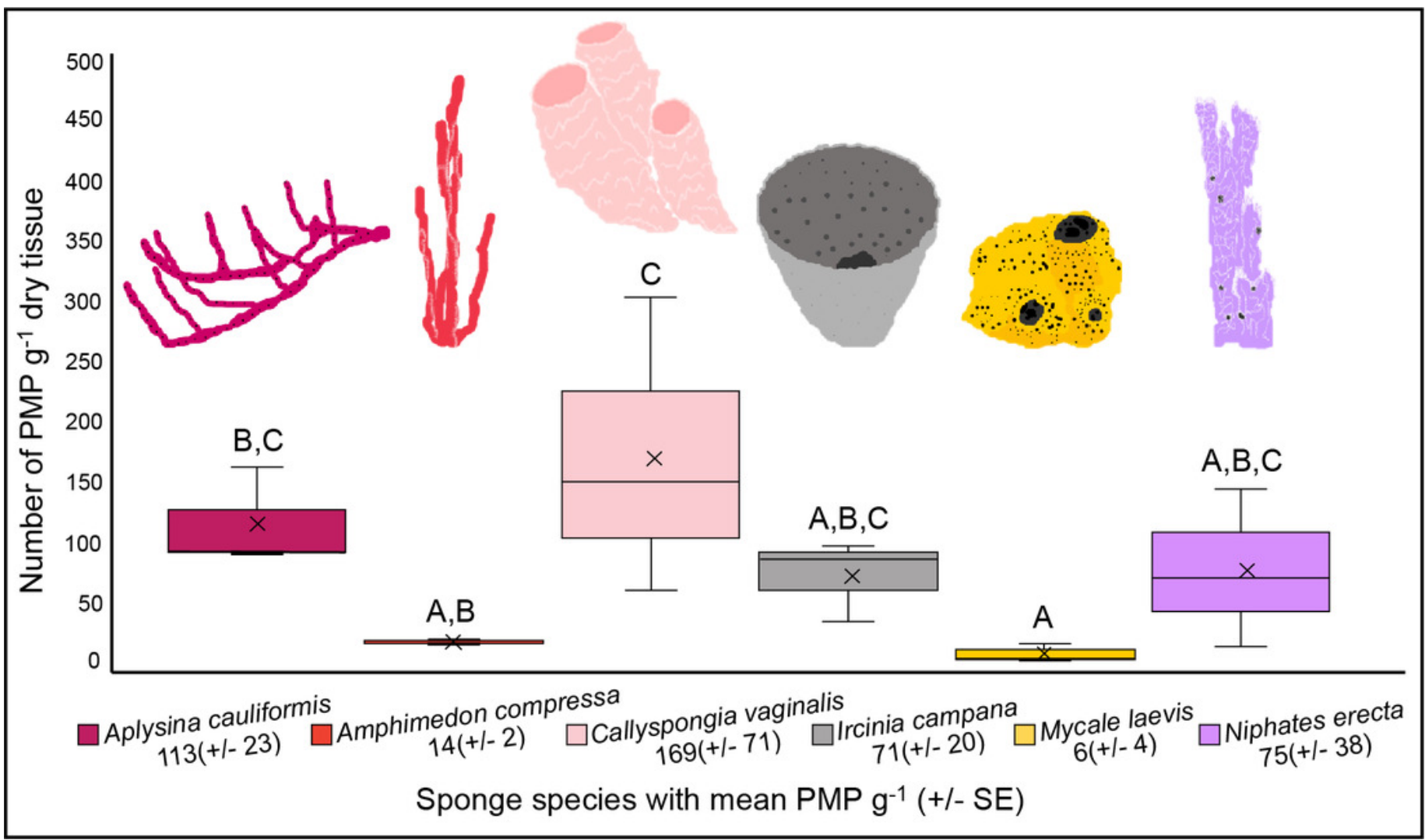

